\title{
Slovak Republic: 2011 Article IV Consultation-Staff Report; Informational Annex; and Public Information Notice on the Executive Board Discussion
}

Under Article IV of the IMF's Articles of Agreement, the IMF holds bilateral discussions with members, usually every year. In the context of the 2011 Article IV consultation with the Slovak Republic, the following documents have been released and are included in this package:

- $\quad$ The staff report for the 2011 Article IV consultation, prepared by a staff team of the IMF, following discussions that ended on April 12, 2011, with the officials of Slovak Republic on economic developments and policies. Based on information available at the time of these discussions, the staff report was completed on May 13, 2011. The views expressed in the staff report are those of the staff team and do not necessarily reflect the views of the Executive Board of the IMF.

- $\quad$ A supplement to the staff report.

- $\quad$ A Public Information Notice (PIN).

The policy of publication of staff reports and other documents allows for the deletion of market-sensitive information.

\author{
Copies of this report are available to the public from \\ International Monetary Fund • Publication Services \\ $70019^{\text {th }}$ Street, N.W. • Washington, D.C. 20431 \\ Telephone: (202) 623-7430 • Telefax: (202) 623-7201 \\ E-mail: publications@imf.org Internet: http://www.imf.org
}

\section{International Monetary Fund Washington, D.C.}




\section{INTERNATIONAL MONETARY FUND}

\section{SLOVAK REPUBLIC}

\section{STAFF REPORT FOR THE 2011 ARTICLE IV CONSULTATION}

May 13, 2011

\section{KEY ISSUES}

Slovakia has swiftly recovered from a deep recession, and is facing a favorable mediumterm macroeconomic outlook, with real GDP projected to grow by around 4 percent per year. Against this backdrop the policy focus should shift from crisis response to enhancing the foundations for long-term growth and stability while addressing the crisis-induced deterioration of the fiscal position.

Fiscal policy: reducing the general government deficit to below 3 percent of GDP in 2013. A significant consolidation this year is projected to narrow the deficit from almost 8 percent of GDP in 2010 to about 5 percent of GDP. Achieving the 2013 deficit target will still be challenging, however, and pressures to adopt low-quality measures or prematurely cut taxes will have to be resisted.

The financial sector: as banking sector conditions improve with the economic recovery, remaining vigilant and monitoring unfolding risks, particularly with regard to exposure of foreign parent banks to sovereign risk, housing loans and signs of accelerating credit growth. Improving the liquidity of the secondary government bond market could support capital market development overall.

Unemployment: reducing the high long-term unemployment. The crisis caused the already high unemployment to surge, and long-term unemployment of low-skilled and young workers has risen to among the highest in the EU, in spite of the strong recovery. Addressing the unemployment problem will require a broad range of policy actions.

Medium-term growth: focusing on productivity gains as the key to achieving continued robust growth and, in combination with labor market flexibility and wage moderation, safeguarding external competitiveness. Sustaining efforts to build and enhance human capital, further improve the business environment and foster competition, will help boost productivity. 
Approved By

Anne-Marie Gulde-Wolf and Thomas Dorsey
Discussions took place in Bratislava from March 30 to April 12, 2011. The staff team comprised of Messrs. De Broeck (FIN, head), Abdel-Kader, Mehrez, and Sandri (all EUR)

\section{CONTENTS}

INTRODUCTION

RECENT DEVELOPMENTS AND OUTLOOK __ 4

A. A Recovery Led by Export-oriented Manufacturing Sector ___ 4

B. Outlook and Risks __ 6

FISCAL POLICY_SETTING A CREDIBLE CONSOLIDATION PATH ___ 10

FINANCIAL SECTOR-ADVANCING THE FINANCIAL SECTOR WHILE ENHANCING

SAFEGUARDS

STRUCTURAL POLICY_TACKLING UNEMPLOYMENT AND REGIONAL DISPERSION 24

STAFF APPRAISAL 27

Tables

1. Selected Economic Indicators, 2006-15 29

2. Fiscal Operations of the Consolidated General Government, 2006-15 30

3. Medium-Term Balance of Payments, 2006-15 31

4. Financial Soundness Indicators for the Banking Sector, 2008-10 32

Figures

1. Recent Sector Developments, 2007-10 8

2. Inflation and Monetary Developments, 2004-10 9

3. Selected Fiscal Indicators 18

4. Financial Indicators, 2005-10 22

5. Labor Market Indicators, 2004-10 26 
Boxes

1. Public Investment and Absorption of the EU Funds in Slovakia 16

2. The System of Social Security Contributions in Slovakia 17

3. Sovereign Bonds Yields

Annexes

I. Medium- and Long-Term Fiscal Issues in Slovakia 33

II. Slovakia's Financial Sector 


\section{INTRODUCTION}

1. Following a deep but relatively short recession, the economy is returning to robust growth. Reflecting the importance of the exportoriented manufacturing sector, Slovakia benefited from the recovery in global demand for manufacturing goods. The surge in exports and expansionary fiscal and monetary policies against the background of a relatively sound financial sector have resulted in robust growth since the second half of 2009.

2. The strong economic rebound in $\mathbf{2 0 1 0}$ and an upbeat outlook shift the policy focus from crisis prevention to normalization of policies with medium-term focus. Fiscal consolidation, which started with the 2011 budget, will have to continue with a view to achieving a medium-term sustainable target anchored by an effective fiscal framework. Strengthening mediumterm fiscal planning, improving governance, and enhancing the efficiency of tax collections are also priorities. The financial sector should be further developed and deepened, in tandem with steps to reduce risks and limit rapid credit growth. Reducing the high unemployment rate, particularly in less prosperous regions, would be essential to enhancing welfare and maintaining robust medium-term economic growth. Strong productivity growth will be the key for maintaining external competitiveness.

\section{RECENT DEVELOPMENTS AND OUTLOOK}

\section{A. A Recovery Led by Export-oriented Manufacturing Sector}

3. Real GDP growth swung from a negative 4.7 percent in 2009 to 4 percent in 2010. The recovery, which has been larger than in most of Slovakia's neighbors, was export led and supported by an expansionary fiscal policy. Consumer confidence is recovering, but the pace is

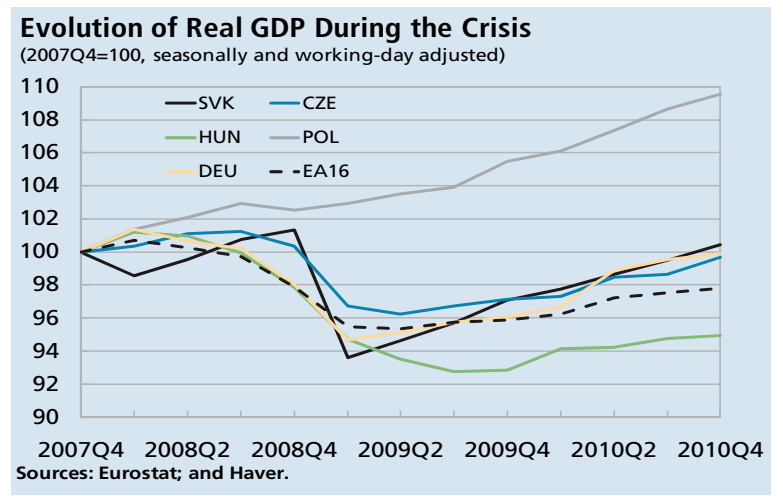

very slow and private consumption remains subdued.

\section{Slovakia benefited from the surge in} global demand for manufacturing goods. The share of manufacturing in GDP is about 35 percent in Slovakia, compared to about 20 percent on average in the EU area. It is composed mainly of transportation equipment, machinery and electrical equipment. As the global demand for these goods expanded in 2010, following their collapse in 2009, Slovakia's exports surged. 


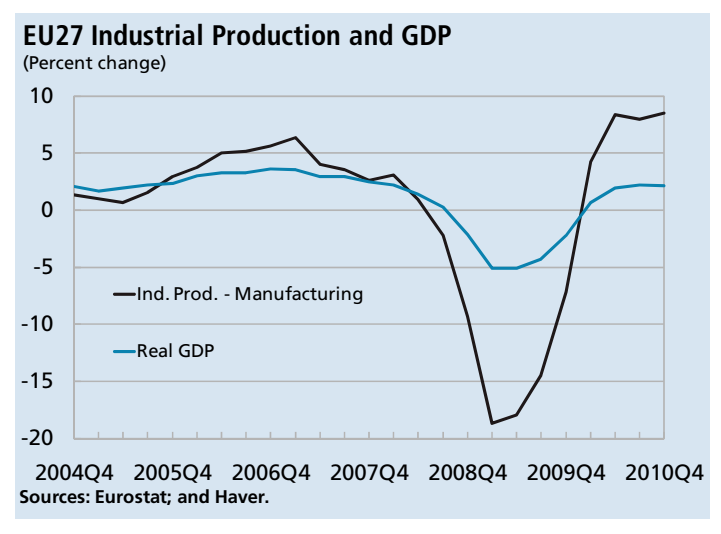

5. External competitiveness has remained robust and the exchange rate is broadly in equilibrium. Export of goods has expanded rapidly, reaching pre-crisis level by end-2010, and Slovakia gained market share. The current account deficit narrowed to 2 percent of GDP in 2010 from more than 6 percent of GDP before the crisis. While the trade balance (goods) swung into surplus, the income balance remained negative reflecting the relatively large negative net international investment position (approaching 70 percent of GDP). However, excluding FDI, the negative net investment position is only around 10 percent of GDP. The manufacturing sector's real effective exchange rate (REER) based on unit labor cost remained stable, and CGER calculations suggest that the exchange rate is broadly aligned with its estimated equilibrium value.

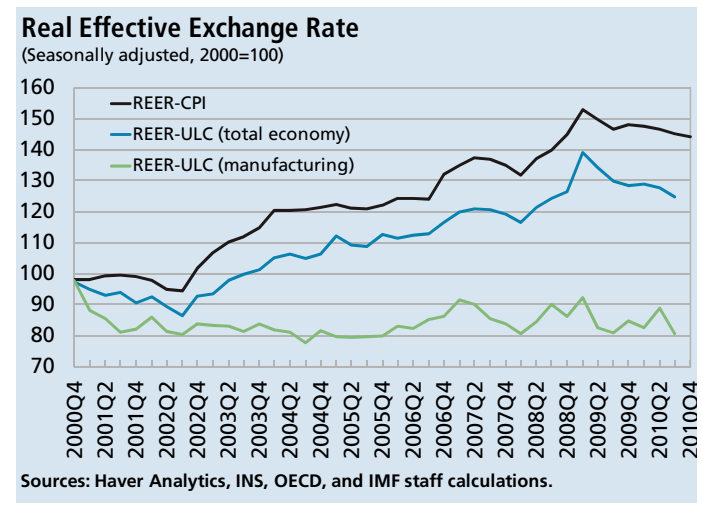

\section{Financial conditions and the situation} of the financial sector have improved. Credit growth is recovering gradually, and monetary conditions are supportive with a low interest rate and a modest real effective exchange rate depreciation. At the same time, banks have enhanced their balance sheet and improved capital and liquidity ratios. Profits rebounded in 2010, reflecting cost cutting measures, higher interest rate spreads and lower provisions, notwithstanding a still high level of nonperforming loans.

\section{CPI inflation dropped to among the} lowest in the euro zone in 2010, but jumped in early 2011. Weak domestic demand against a background of low energy and food inflation reduced inflation to a historically low rate of 1 percent (y-o-y) in November 2010. However, reflecting the global increase in the price of oil and other commodities, and in part because of indirect tax hikes at the beginning of 2011, CPI inflation jumped to 3.2 percent (y-o-y) in January 2011 and further accelerated to 3.8 percent in March. However, the projected tightening of monetary conditions will help reduce the impact of secondround effects.

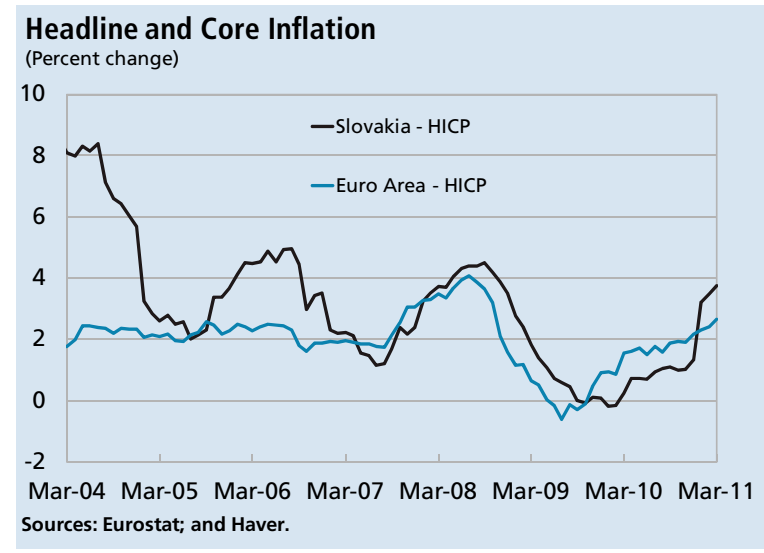


8. Notwithstanding the robust GDP growth, the general government deficit remained high in 2010, at 7 3/4 percent of GDP. The deficit had widened to about 8 percent of GDP in 2009, as revenue contracted sharply and spending continued to expand at a fast pre-crisis pace. Although revenue recovered in 2010, the pace fell short of GDP growth, reflecting the exportled recovery and subdued private consumption and employment. With expenditure growth declining only marginally, the deficit was almost unchanged from its 2009 level.

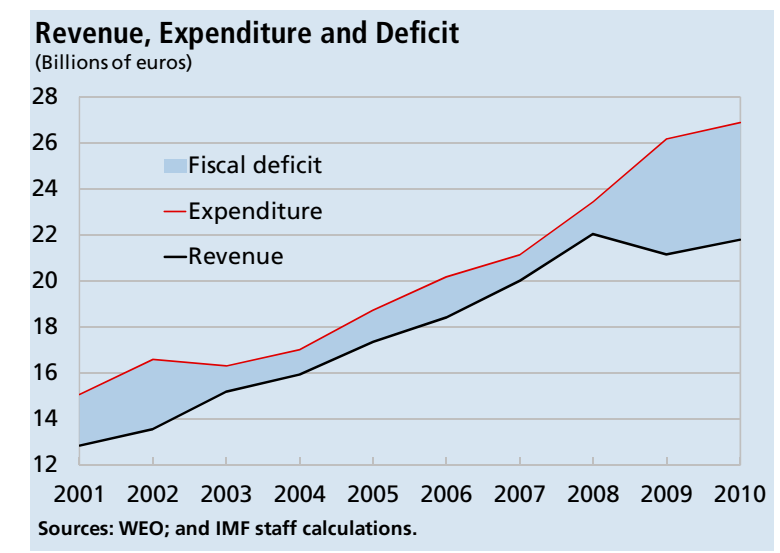

9. The economic recovery has had little positive effect on employment. Unemployment,

\section{B. Outlook and Risks}

\section{Staff's Views}

10. The outlook is for robust balanced growth, but significant risks remain. Although private consumption and investment have remained subdued so far, the expected modest recovery in employment and economic sentiment would bring some growth in domestic demand. This would help offset the withdrawal of fiscal support and which was already relatively high prior to the recession, spiked to over 14 percent, and is even higher among low-skilled workers and in less prosperous regions. As workers with lower-thanaverage wages were disproportionally affected by the employment cuts and also reflecting wage indexation mechanisms, nominal wage growth only briefly turned negative in 2009 and bounced back to above 5 percent (year-on-year) in 2010. With the turnaround in economic activity, employment started to recover in late 2010, but the gains, so far, have been small and insufficient to prevent an increase in long-term unemployment.

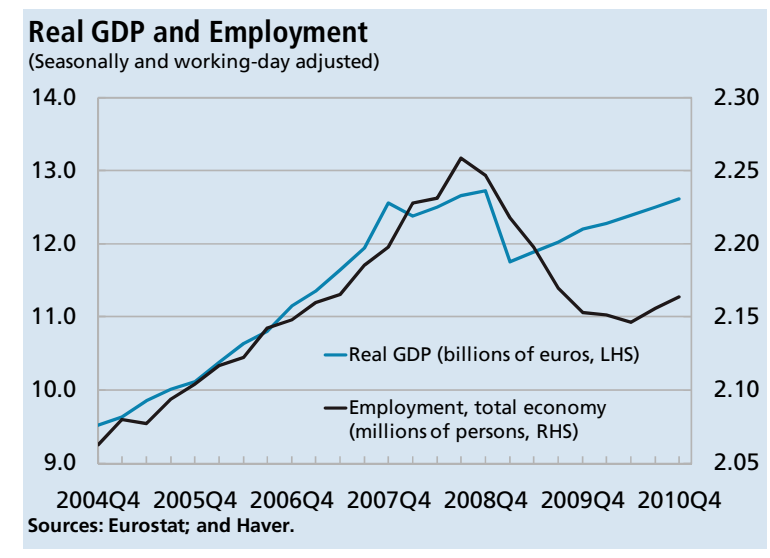

moderation of export growth. Notwithstanding, because Slovakia's exports to Germany are largely intermediate products for goods with export destinations outside the EU, the impact of the projected slowdown in Germany would be limited. Overall, real GDP is projected to grow by about 3 3/4 percent in 2011 and by about 4 1/4 percent in 2012-15, among the strongest performances in the 
EU but still significantly below the pre-crisis rate of expansion.

\section{The upbeat outlook is supported by} positive high frequency indicators. Economic sentiment continues to improve, real estate prices are stabilizing, industrial production is surging, and employment growth is finally starting to pick up.

\section{External and domestic risks remain} substantial, some improvement since last year notwithstanding. The global economic environment remains clouded, facing risks associated with simultaneous and uncoordinated fiscal consolidation efforts, possible loss of market confidence related to sovereign risk developments, and uncertain oil and other commodity prices developments. Domestically, a renewed decline in real estate prices would hinder consumption, and investment. A loss of fiscal credibility, if the government fails to achieve fiscal consolidation, would increase interest rates and reduce investment and private consumption.

\section{Authorities' Views}

13. While robust growth is projected to continue in 2011 on the back of the export sector, private consumption will remain subdued. Expectations related to the fiscal consolidation increase consumer uncertainty, which, in combination with lower employment growth, translates into a less optimistic projection of households' consumption in 2011. Overall, real GDP in 2011 is projected to grow by 3.4 percent, driven primarily by foreign demand, investment and stocks.

14. However, from 2012 onwards real GDP growth is projected to accelerate to 4.8 percent. Reflecting the projected recovery in employment, private consumption is expected to rebound and expand by 3.5 percent in 2012. Export growth and investment will continue to be robust reflecting the global outlook.

\section{Against the background of the global} increase in food and commodity prices, and the increase in VAT and excise taxes, inflation is expected to increase in 2011 onward. Inflation is expected to reach 3.4 percent in 2011, with the higher VAT and excise taxes and other fees contributing near 1 percentage point. Reflecting the global environment, inflation is expected to decline only slightly in 2012 and remain at about $31 / 2$ percent onward. 


\section{Figure 1 Slovak Republic-Recent Sector Developments, 2007-10}

\section{Real GDP growth has recovered...}

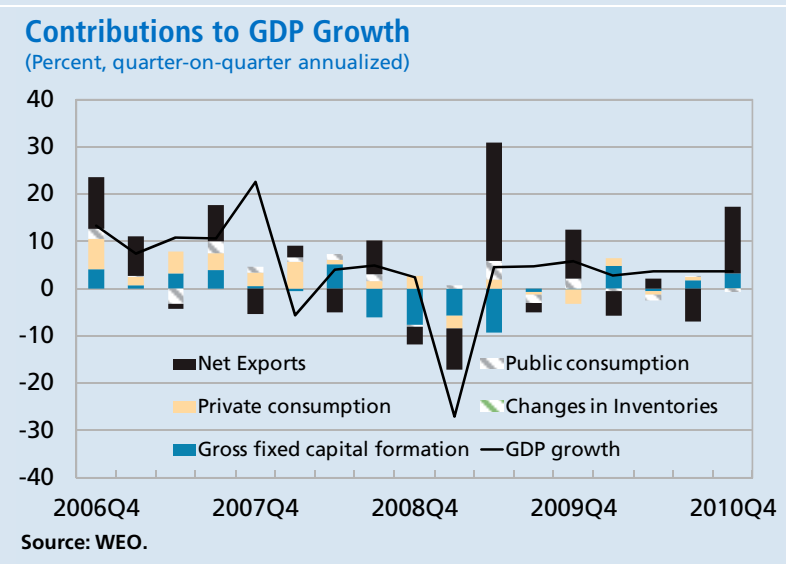

...and was led by export-oriented manufacturing sector.

Industrial Production, Retail Trade and Exports (2007=100)

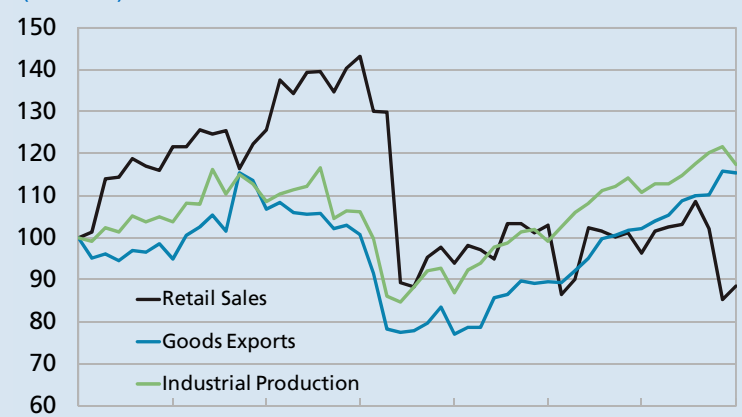

Jan-07 Aug-07 Mar-08 Oct-08 May-09 Dec-09 Jul-10 Feb-11 Sources: SOSR; Eurostat; and Haver.

\section{...as well as property prices...}

\section{Property Prices}

(Euros per square meter)

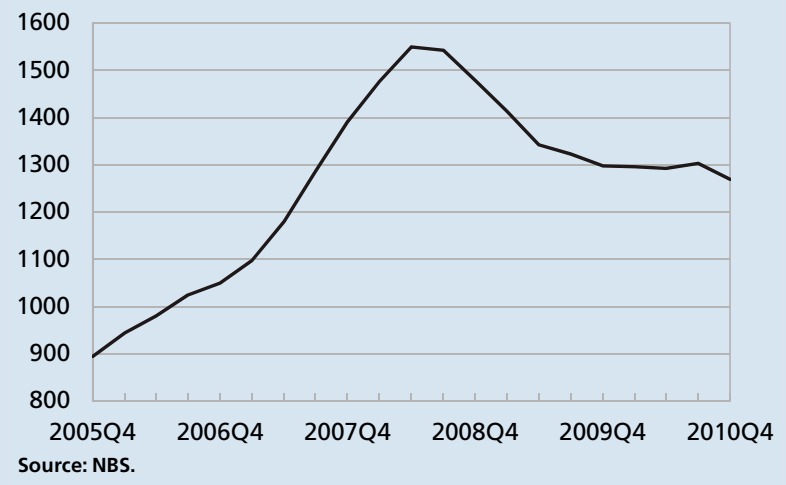

...more than in other countries in the region...

Growth, 2010

(Percent change)

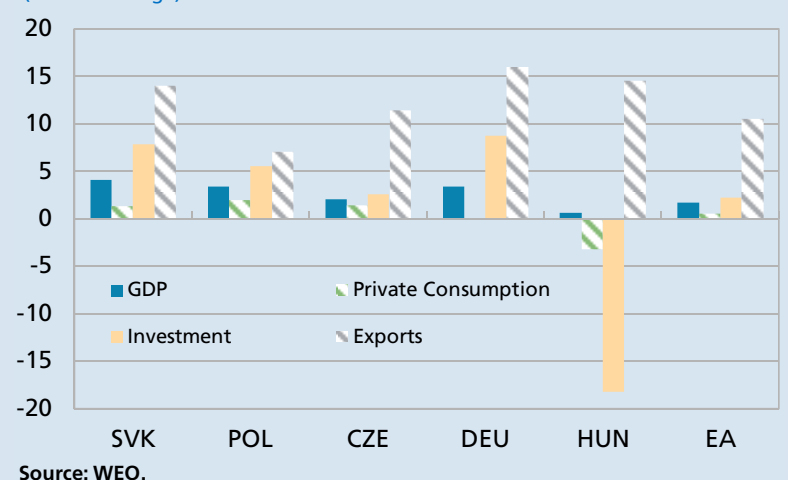

Source: WEO.

\section{Employment has stabilized...}

Wages and Employment

(Year-on-year percent change)

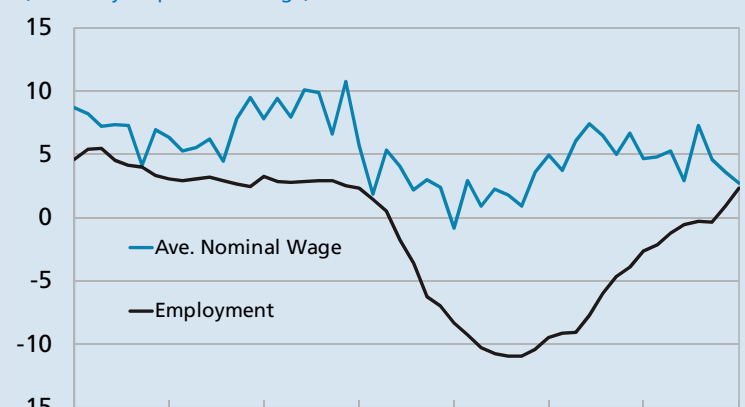

$-15$

Jan-07 Aug-07 Mar-08 Oct-08 May-09 Dec-09 Jul-10 Feb-11 Sources: SOSR; Eurostat; and Haver.

\section{...and confidence is rebounding.}

\section{Confidence Indicators}

(Percent balance, seasonally adjusted)

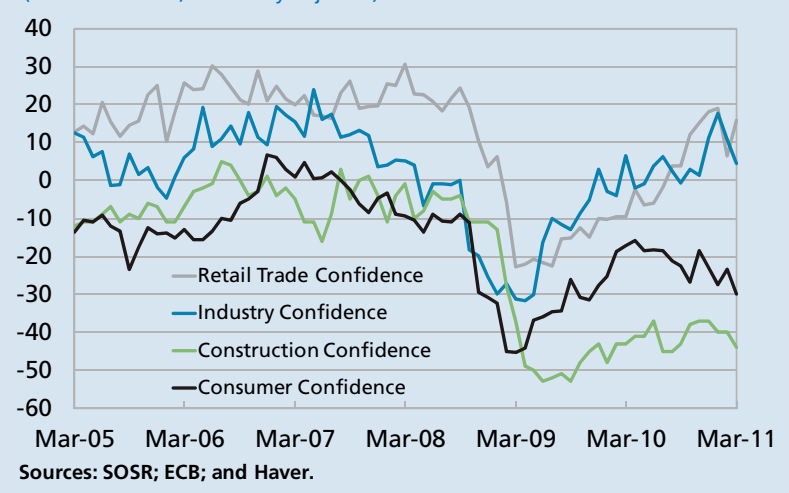




\section{Figure 2 Slovak Republic_-Inflation and Monetary Developments, 2004-10}

\section{Inflation has been subdued...}

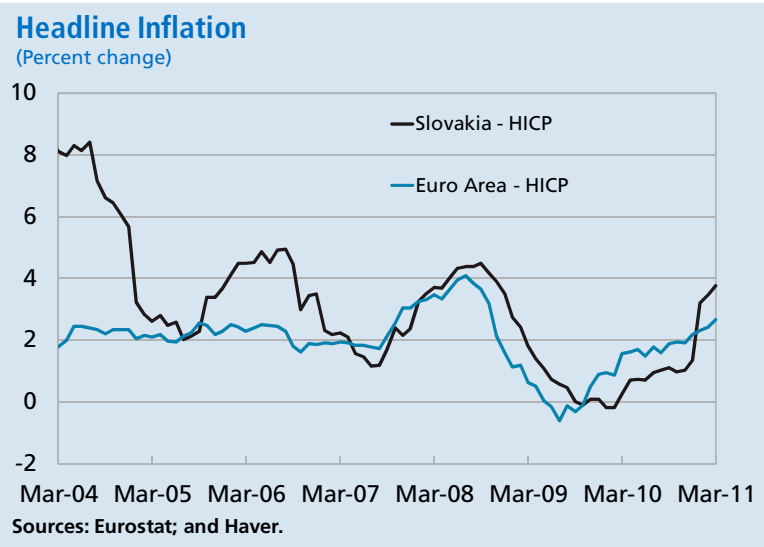

The aggressive cut in interest rates by the ECB...

Policy Interest Rate

(Percent)

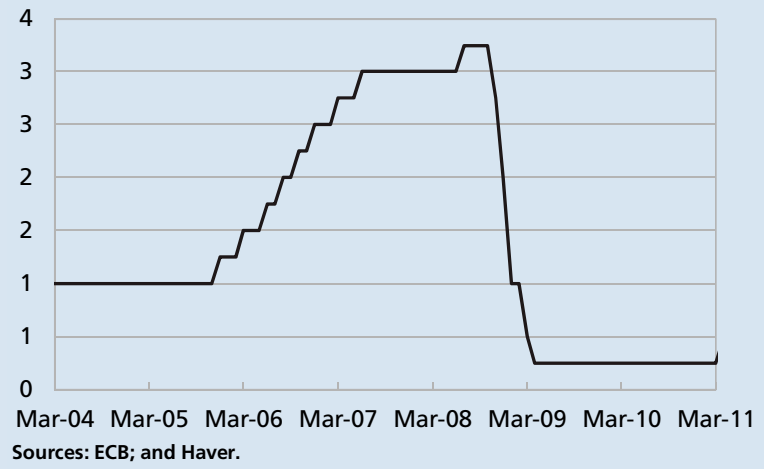

\section{Money supply is recovering...}

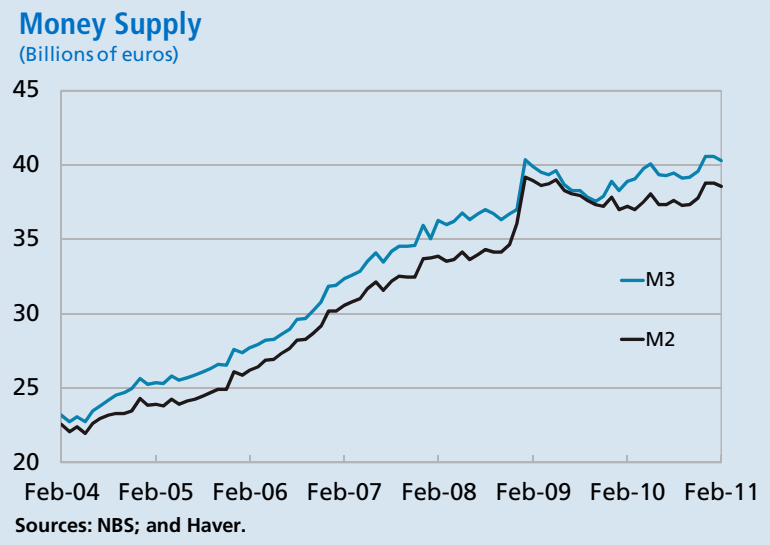

...reflecting low food and energy inflation and weak domestic demand.

Contributions to Inflation

$$
\text { (Percent) }
$$

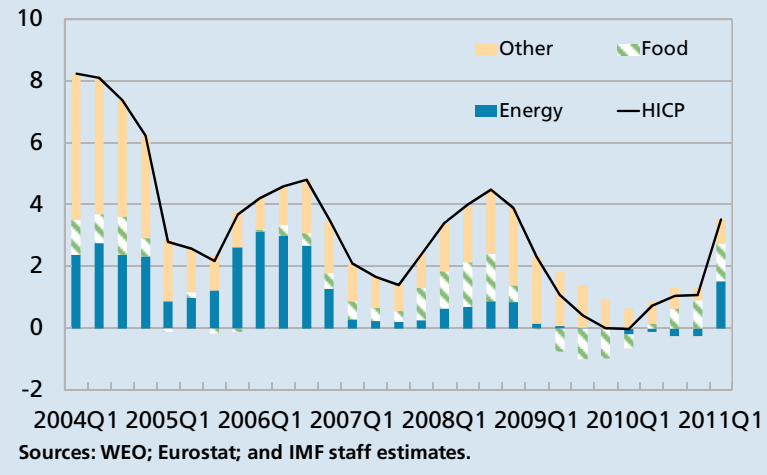

...reduced corporate lending rate but not consumer credit and mortgage rate.

\section{Lending Rates}

(Percent)

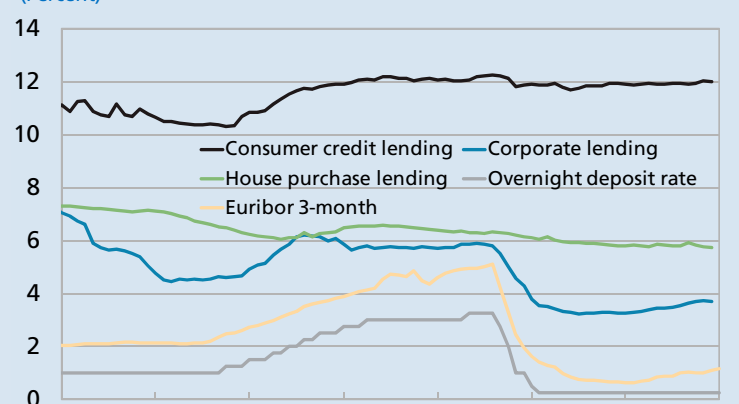

Mar-04 Mar-05 Mar-06 Mar-07 Mar-08 Mar-09 Mar-10 Mar-11 Sources: NBS; ECB; and Haver.

\section{As well as private sector credit.}

Credit to Private Sector (Billions of euros)

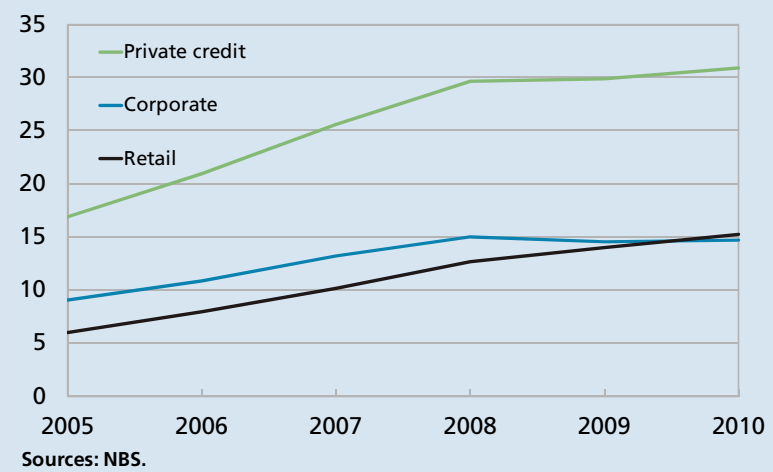




\section{FISCAL POLICY -SETTING A CREDIBLE}

\section{CONSOLIDATION PATH}

With the stabilization of growth the key fiscal policy challenge is to set a consolidation path toward a medium-term target that ensures sustainability. Following important fiscal adjustment this year, consolidation will need to continue during 2012-13 with a view to bringing the government deficit below 3 percent of GDP in 2013. The authorities' fiscal policy priorities should guide the composition of the adjustment. Simultaneously achieving these priorities and the consolidation targets will require broad-ranging revenue efforts and expenditure reallocation and cuts.

\section{Background}

16. In spite of the recovery, the general government deficit remained high in 2010, at $73 / 4$ percent of GDP. The deficit had widened to about 8 percent of GDP in 2009, as revenue contracted sharply and spending continued to expand at a fast pre-crisis pace. Reflecting a subdued revenue performance and continued strong expenditure growth, the deficit was almost unchanged from its 2009 level, and was among the highest in the region.

\section{Overall Fiscal Balance}

(Percent of GDP)

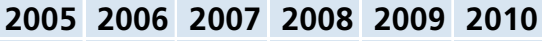

Slovakia

Czech Republic

\begin{tabular}{l|l|l|l|l|l|}
-2.8 & -3.2 & -1.8 & -2.1 & -7.9 & -7.8 \\
\hline
\end{tabular}

Poland

$-3.6 \quad-2.6$

$-4.1 \quad-3.6$

$-7.9 \quad-9.3$

$-0.7$

$-2.7$

$-5.8 \quad-4.9$

Hungary

$-0.7$

Romania $-2.5$

Euro Area

$-2.5 \quad-1.3$

Sources: National authorities; and WEO.
17. The 2011 budget contains a frontloaded fiscal adjustment. It includes various revenue and expenditure measures amounting to about $2 \frac{1}{2}$ percentage points of GDP. Expenditure cuts include a reduction in the public wage bill, intermediate consumption, subsidies, and investment. On the revenue side, the main measures are a temporary rise in the VAT rate by 1 percentage point to 20 percent and higher excise taxes.

18. Although the general government debt rose rapidly during the crisis, it remains relatively low and has a relatively long maturity. The debt reached 41 percent of GDP in 2010. The foreign currency component is negligible following euro adoption, and the maturity profile is spread uniformly over the next 10 years. The domestic financial sector is the main investor in Slovak government bonds, providing additional stability. Nevertheless, contingent liabilities associated with state-owned companies and the National Bank of Slovakia (NBS) could add to the 
debt. The NBS has a negative equity position, ${ }^{1}$ which does not have immediate implications for its operations, but will need to be covered within a reasonable period of time according to $E C B$ guidelines to ensure NBS financial independence.

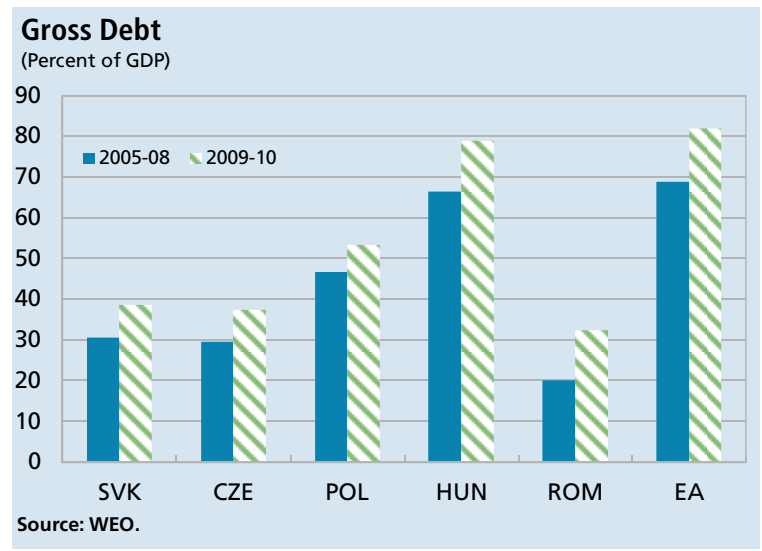

19. Market confidence, so far, remained intact. The relatively favorable debt position, the rapid rebound in economic growth and the credibility of the government's commitment to fiscal consolidation have maintained market confidence. Spreads over corresponding euro zone benchmark German bonds, at around 130 basis points, and CDS spreads, at below 100 basis points, are relatively low. Primary market access has remained smooth, as reflected in very successful large bond issuances in mid-February and mid-April.

\footnotetext{
${ }^{1}$ Negative equity of around euro 4.5 billion is related to unrealized accumulated losses, which are mainly the result of foreign exchange market intervention before euro accession. More recent losses reflect a drop in the market value of the NBS's portfolio of eurodenominated securities, including instruments from the euro-area periphery.
}
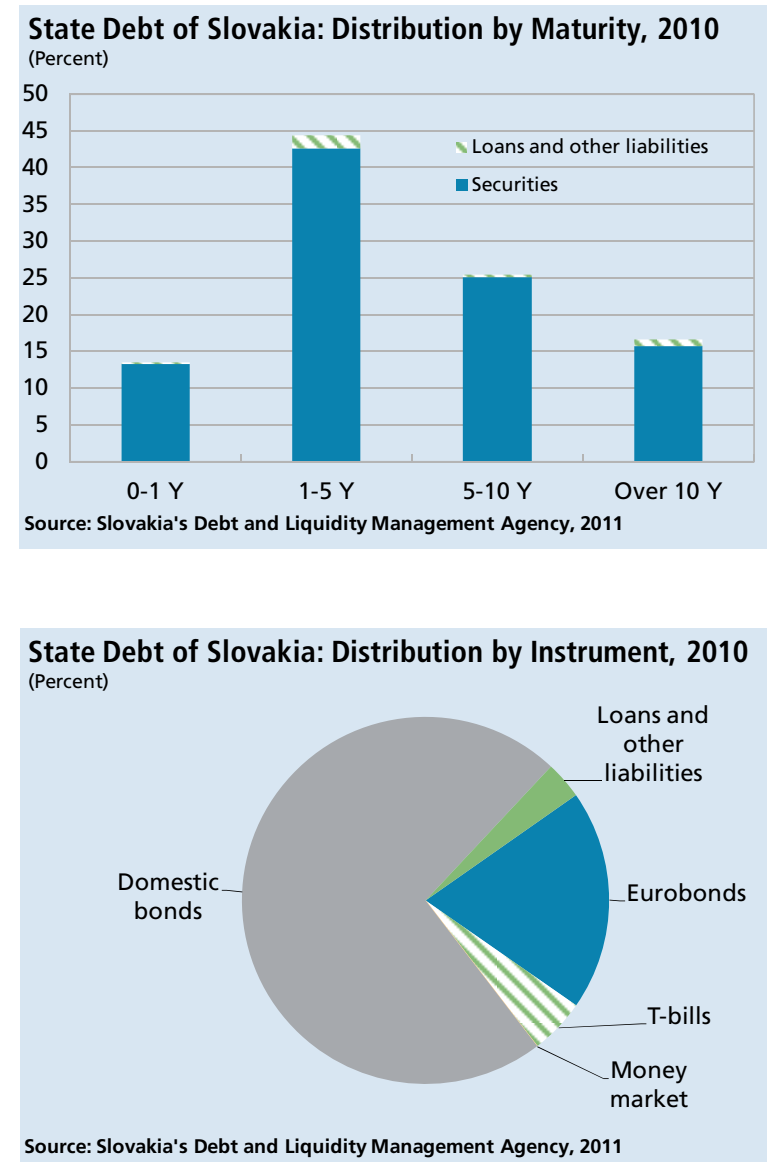

20. The authorities are considering a significant reform to simplify and harmonize social security contributions. The reform, to be implemented in the beginning of 2012, would reduce incentives to opt for self-employed status, and bring down collection costs. The proposed reform will add the employer's social security and health contribution (about 35 percent) to the wage base considered for tax purposes. Out of the redefined gross wage employees will pay a combined 48.6 percent social security and health contribution and a 19 percent income tax. Selfemployed will face an increase in social security and health contribution and reduced deductions. Overall, the reform, in its current design, will shift collections from social security contribution to 
income tax, and is projected to reduce revenue collections slightly. The reform maintains the contribution rate to the second pension pillar at 9 percent, which is high by CEE standards (Annex I).

21. A broad fiscal institutional reform is under preparation. The plans include a constitutional debt limit at 55 percent of GDP (below the Maastricht threshold) with increasingly strong sanctions-starting with a letter to Parliament, followed by an expenditure freeze, and ultimately the resignation of the governmentwhen debt exceeds 45 percent of GDP. The debt ceiling will be complemented with rolling mediumterm expenditure ceilings at the state level. Enhanced debt and debt service rules and a strict no bail-out clause are envisaged at the municipal level. An independent fiscal council will be tasked with preparing a sustainability report, setting the expenditure ceilings and evaluating compliance with debt and expenditure rules. Broad political support is sought for the reforms to ensure their viability and durability.

22. In addition, restructuring and privatization of state-owned companies is on the agenda. The authorities plan to transfer part of the activities carried out by state-owned companies to the private sector; restructure some companies (railways, Slovak radio and TV); and privatize shares in the Telecom Company, and several city heating companies. Other state-owned companies, including the Bratislava airport, will be slated for long-term leasing. These plans will help eliminate public sector losses, and the associated need for budget support, and repay part of the public sector debt.

\section{Staff's Views}

23. The $\mathbf{2 0 1 1}$ deficit is projected to decline to below 5 percent of GDP on the back of a welcome consolidation effort and further economic recovery. The size of the adjustmentaround $2 \frac{1}{2}$ percentage points of GDP_and its composition are broadly appropriate. Implementing the planned expenditure cuts in full, particularly with regard to wages and municipal spending, may prove to be difficult. However, some higher-thanbudgeted revenue on account of the improved economic conditions would help offset expenditure slippages.

\section{Fiscal consolidation should continue} with the aim of reducing the deficit to below 3 percent of GDP by 2013. Adhering to this anchor, in line with EU requirements, will help maintain market confidence and keep Slovakia's interest premium low. The front-loaded adjustment in 2011 allows for a gradual consolidation path of about 1 percent of GDP a year during 2012-13. Pacing the adjustment will help to minimize the adverse impact on growth and to limit recourse to lower-quality and possibly unsustainable measures.

\section{Fiscal adjustment efforts need to} continue beyond 2013. A deficit near the 3 percent of GDP Maastricht ceiling provides no room for counter-cyclical fiscal policy in case of a downturn. Moreover, Slovakia has to prepare for a substantial increase in ageing-related expenditure pressures (see Annex I), and efforts to reform the 
pension and health systems need to continue. A deficit of 1 percent of GDP would be an appropriate medium-term target. It would leave room for considerable counter-cyclical fiscal policy, and reduce the debt-to-GDP ratio to less than 25 percent. A 1 percent of GDP deficit at the same time should allow for substantial capital and other growth enhancing expenditures, especially if the reforms to improve tax collections start to bear fruit.

\section{The authorities' fiscal policy priorities} should guide the composition of the 2012-13 consolidation efforts. Priorities could include supporting growth through infrastructure investment and education; reducing the high unemployment and income disparity across regions; and strengthening the efficiency of the tax system. In addition, improving the quality and ensuring the financial soundness of the health care system remain a standing priority. The measures should include incentives to use generic pharmaceutical substitutes; co-payments for doctors' visits and hospital care; and a stricter basic health care package, allowing some variations in basic insurance premiums (see IMF Working Paper No. 07/226, and recent OECD recommendations).

\section{Simultaneously achieving these} priorities and the consolidation targets will require fiscal planning, and broad-ranging revenue efforts and expenditure reallocation and cuts. The authorities' projections are sound and the proposed measures reflect a credible commitment to achieve the 2013 deficit target. However, only raising some minor taxes and concentrating the expenditure efforts on cutting wages and operational costs as envisaged by the authorities may not be sufficient to meet their evolving priorities, and may erode some essential government services to unsustainably low levels. Moreover, it could lead to possible reductions in capital expenditures. Against this backdrop, the emphasis should be on raising revenue and on expenditure reallocation.

\section{To enhance the allocation of resources,} the medium-term consolidation path should be accompanied by an expenditure growth ceiling. Capping expenditure growth in real terms for 2012-15 would set a consolidation path toward a deficit of 1 percent of GDP. It would also facilitate the transition to the expenditure rules which are envisaged in the fiscal framework reform package, and which would be set by the proposed fiscal council according to the economic conditions.

\section{The recently-proposed reform of the} social security contributions system is a step in the right direction. The current system is inefficient, complicated, and inequitable. It features eighteen contribution rates; three different assessment bases with various minimums and maximums; and a large number of discretionary allowances and exemptions. In addition, selfemployed pay significantly lower contributions. The reform simplifies and harmonizes the system, and to some extent improves equity. However, the builtin revenue loss, albeit estimated to be small at around $1 / 4$ percentage point of GDP annually, is a concern in light of the fiscal consolidation needs and the risk of larger losses than projected. It would be preferable for the proposed reform to remain 
focused on the main objectives of simplification, transparency and reduced incentives to opt for selfemployed status and avoid major cuts in the rates, for which there is no room, or non-transparent changes. Maintaining the second-pillar contribution rate at its current level will contribute to the pillar's sustainability.

30. Steps to harmonize and simplify social security contributions and to unify revenue collection could be complemented with efforts to broaden the tax base and improve the efficiency of VAT collection. Efforts to remove various tax deductions and exemptions should continue. The VAT revenue, as percentage of GDP, is the lowest in the region, despite having comparable rates, indicating an implementation gap and the need for improving VAT administration and harmonizing tax collections. Aligning the collection of income and social contributions could also help enhance the efficiency of tax collection. However, net revenue gains from harmonization, unified collection and improved VAT administration would be slow to materialize and should not be expected to contribute to the 2012-13 consolidation effort.

31. The plans to reform the fiscal framework are welcome. The proposals are guided by standards of best practice and are expected to enhance commitment, discipline and transparency. Efforts to secure broad political support with a view to enshrining the key reforms into the Constitution are particularly important. Broader efforts to increase fiscal transparency, including steps to clearly report and explain the
NBS's negative equity in its financial statements, should be considered and not be delayed until after the fiscal framework reform is agreed.

\section{Authorities' Views}

32. The 2011 consolidation measures, including wage cuts, will be implemented in full and the deficit target will be met. As growth continues to be mostly export-driven, no significant over performance of revenue can be expected. However, the expenditure consolidation, including wage cuts, will be carried out according to plans. Indeed, the development of expenditures in 2011:Q1 is in line with planned executions.

\section{The government is committed to} bringing the deficit to below 3 percent of GDP by 2013 . To reduce the deficit in 2012-13 additional measures will be required and are being discussed. These measures will include both revenue and expenditure efforts with the goal of reducing the deficit to 3.8 percent of GDP in 2012 and to below 3 percent of GDP by 2013. A freeze in public wages, further cuts in operational costs, and a substantial increase in real estate taxes could contribute importantly to the consolidation efforts. Adjustment will continue beyond 2013 with a target of about 1 percent of GDP.

\section{Combating tax evasion and unifying} tax collection remain high on the authorities' agenda. Unification of collection of taxes, custom duties, and social security contributions is expected to increase revenue collection. Unification efforts are proceeding according to plan and could be largely completed by end-2012. Net revenue gains 
are not projected to materialize in the near future, and are not incorporated in next year's budget projections.

\section{The fiscal framework and the pension} system are other reform priorities. Discussions are at an advanced stage, and the prospects for achieving a broad agreement on key reforms before end-2011 are good. As to the pension system, reform is essential to help curb expected ageingrelated expenditure pressures and ensure sustainability. The proposed automatic alignment of the retirement age with changes in life expectancy and in the old age dependency ratio will help avoid repeated political discussions on adjustments in the parameters of the first pension pillar. 


\section{Box $1 \quad$ Public Investment and Absorption of the EU Funds in Slovakia}

In contrast to overall investment, which has been relatively high reflecting extensive FDI, public investment has been relatively modest in Slovakia. In 2009, general government investment was among the lowest in the central and eastern European (CEE) region, amounting to about 2.3 percent of GDP. This low level in part reflects the relatively small size of the government, particularly excluding social benefits, subsidies and interest payments (see Annex I).

Government Spending and Public Investment, 2009 1/ (Percent of GDP)

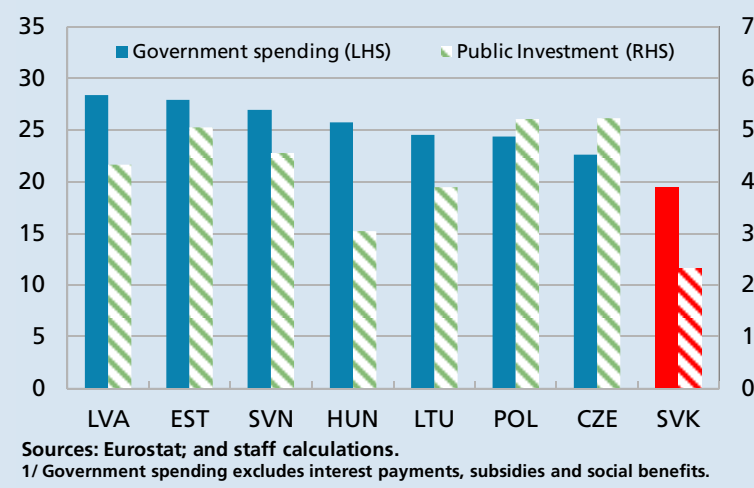

Low public investment appears to have implications for the overall level of infrastructure, which appears to be below the level of infrastructure in other CEE countries. According to the 2011 World Economic Forum's Global Competitiveness report ranking of infrastructure, Slovakia is below most emerging European countries, including regional peers (a higher ranking indicates a less favorable position).

Public Investment in Emerging Europe, 2009

(Percent of total government spending)

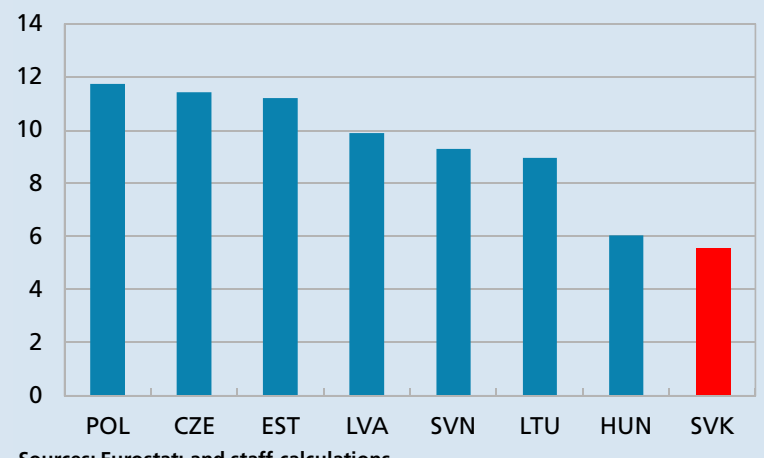

Infrastructure Rankings in the Global Competitiveness Index, 2011

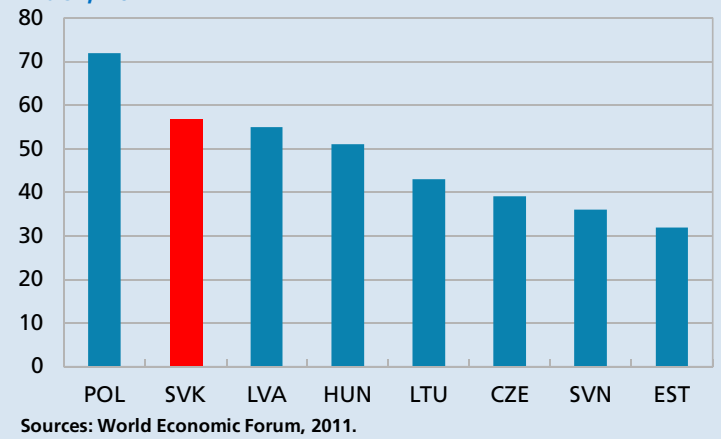

Sources: World Economic Forum, 2011.

In part to help narrow the infrastructure gap with high-income EU member countries, Slovakia receives financial support through EU Funds. For the EU multiyear budget implementation period 2007-13, total available EU fund resources for Slovakia amount to close to 3 percent of GDP per year, including cofinancing from the state budget at about 10 percent of the total (OECD, Economic Survey of the Slovak Republic, 2010). EU funds also serve other purposes, including in agriculture and education, and in part are disbursed directly to private sector recipients (only about $1 / 3$ of the EU funds is available for government). In 2010, Slovakia received a total of euro 1.9 billion in EU funds, euro 653 million of which was disbursed to government-about euro 454 million for capital expenditure and the rest for current expenditures.

Absorption of EU funds is relatively slow compared with other CEE countries, which in part could reflect a different time profile of the planned disbursements. Oversight of the drawing of EU funds has been strengthened, and Slovakia is expected to absorb near 100 percent of its allocation by the end of the 200713 program - as was the case under the previous program.

\section{Allocation of EU-related Spending 1/}

\begin{tabular}{|l|r|r|r|r|r|r|r|r|r|r|}
\hline (Millions of euros) & & & & & & \multicolumn{4}{|c|}{ Projections } \\
\hline & 2006 & 2007 & $\mathbf{2 0 0 8}$ & $\mathbf{2 0 0 9}$ & $\mathbf{2 0 1 0}$ & $\mathbf{2 0 1 1}$ & $\mathbf{2 0 1 2}$ & $\mathbf{2 0 1 3}$ & $\mathbf{2 0 1 4}$ \\
\hline Current expenditure & 85 & 84 & 101 & 138 & 199 & 667 & 321 & 745 & 636 \\
\hline Capital expenditure & 125 & 131 & 115 & 177 & 454 & 464 & 687 & 217 & 175 \\
\hline Total & 210 & 215 & 216 & 315 & 653 & 1131 & 1008 & 962 & 811 \\
Source: National authorities. & & & & & & & & \\
\hline 1/ Only inside the general government. & & & & & &
\end{tabular}


Box 2 The System of Social Security Contributions in Slovakia

\section{Current status:}

The current system of social security and health contributions and income taxes in Slovakia is complex and costly to administer. Employers contribute 35.2 percent, and employees contribute 13.4 percent of gross wages and salaries-part of it for social security and part for health insurance. The amounts are capped by maximum assessment bases that depend on the average wages. All together, there are eight types of insurance; eighteen contribution rates; three different assessment bases (for personal income tax, social security contributions, and a special assessment base for economically-inactive people); various minimum and maximum assessment bases; a large number of discretionary allowances; a set of exemptions based on the employment status (employed, selfemployed or contractual); different social security contributions for the employed and self-employed; and different deductions from gross income for the employed and self-employed for personal income tax purposes.

The favorable treatment of the self-employed distorts incentives and erodes revenue collection. Self-employed can use standardized deduction of 40 percent of income and then pay social security contribution on only half of the net amount. In 2009, the annual income subject to taxes and social security contributions was euro 5,600 for employees and euro 1,700 for the self-employed. Furthermore, approximately 80 percent of the selfemployed who pay social security contributions pay the amount according to the minimum base. As a result on these differences, the number of people claiming such status increased by 34.3 percent between 2004 and 2010.

\section{Proposed changes:}

The main goals of the proposed reform (to be implemented from the beginning of 2012) are to simplify the system, make it more transparent and equitable, and create conditions for the unification of collection of taxes, custom duties, and social security contributions. The main change is to focus on overall labor cost (by adding the employers' total social security contributions to the basic wage) and calculate a "super-gross wage" that would become a universal assessment base for social security contributions and personal income taxes. In addition, the proposed changes entail a standard single health contribution rate (9 percent) and a differentiated social security contribution rate (19 percent for employees, 16 percent for selfemployed and 13 percent for contractual). Besides unifying different assessment bases for different types of insurance, the new arrangement will subject all workers to a uniform assessment base regardless of their employment status. The maximum assessment base will be replaced by maximum nominal contributions.

Because the 19 percent flat income tax is calculated from the super gross wage, the reform implies a shift of taxes from social security contribution to income tax. Based on the current proposed rates, the reform is projected to shift over euro 1 billion from social security contribution to income tax. Overall revenue collection is estimated to decline by about euro 70 million a year. The reform is also combined with a scheme to lower social security contribution rates. If fiscal deficit targets are achieved, rates will be cut by 1 percentage point every year with a maximum of 4 percentage points.

\begin{tabular}{|c|c|c|c|}
\hline \multicolumn{4}{|c|}{$\begin{array}{l}\text { Fiscal Impact of Reforming the Social Security } \\
\text { Contribution System }\end{array}$} \\
\hline \multicolumn{4}{|l|}{ (Millions of Euros) } \\
\hline & 2012 & 2013 & 2014 \\
\hline Impact on social security contributions & -1286 & -1378 & -1490 \\
\hline Impact on other revenues & -284 & -304 & -329 \\
\hline Impact on personal income tax revenue & 1506 & 1611 & 1733 \\
\hline Total budgetary impact & -64 & -71 & -86 \\
\hline Sources: National authorities. & & & \\
\hline
\end{tabular}




\section{Figure 3 Slovak Republic-Selected Fiscal Indicators}

\section{Fiscal deficit increased sharply during the crisis...}

\section{Revenue and Expenditure} (Percent of GDP)

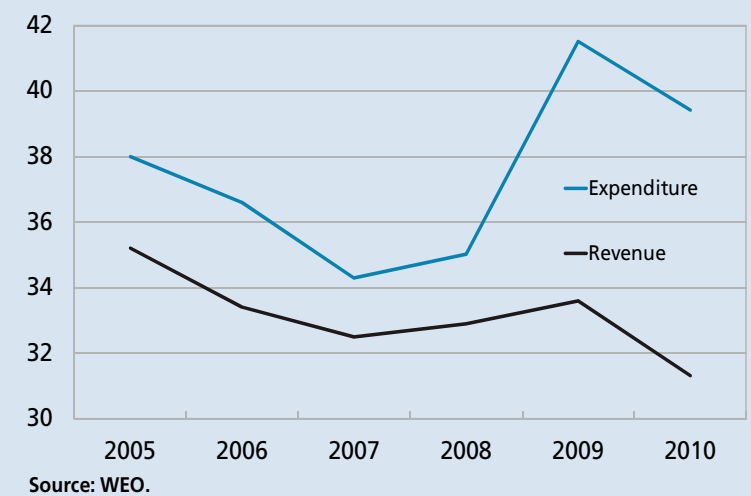

The increase in the deficit was among the highest in the region...

Overall Fiscal Balance

(Percent of GDP)

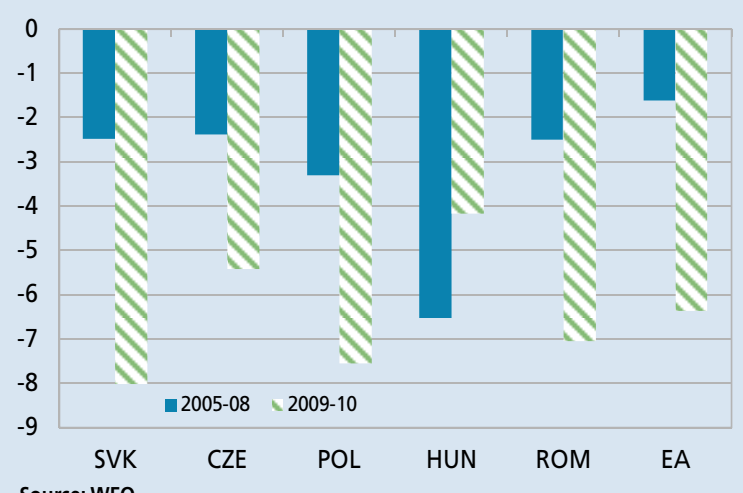

Source: WEO

However, the debt level is still relatively low...

\section{Gross Debt}

(Percent of GDP)

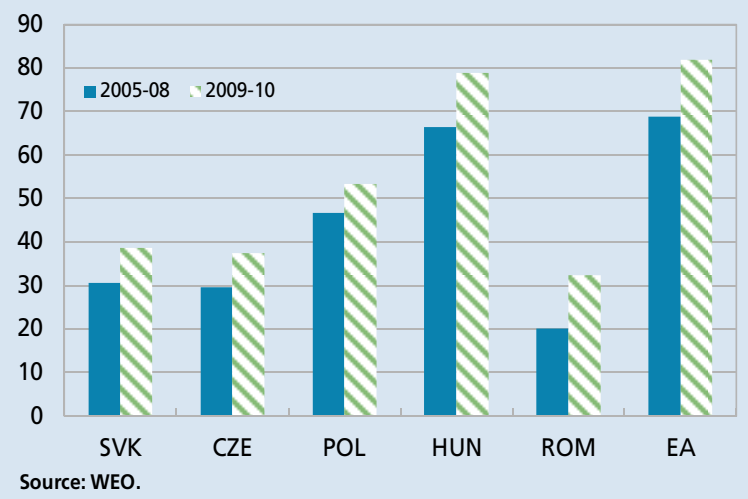

... most of it is structural in nature.

\section{Fiscal Balance}

(Percent of GDP)

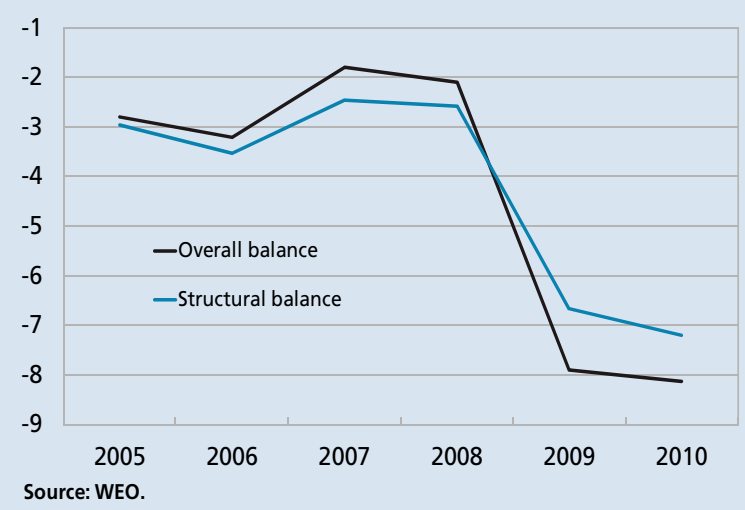

... and has pushed up public debt sharply.

Gross Debt

(Percent of GDP)

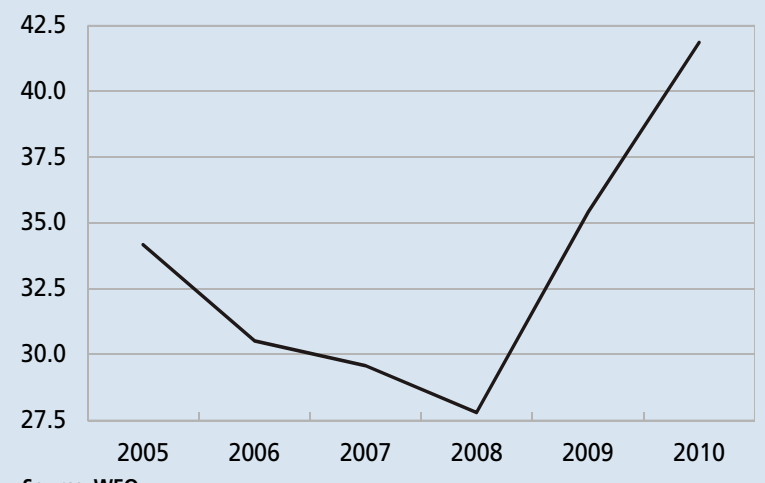

Source: WEO.

... and, hence, market confidence remained intact.

10 Year Government Bond Yields (Percent)

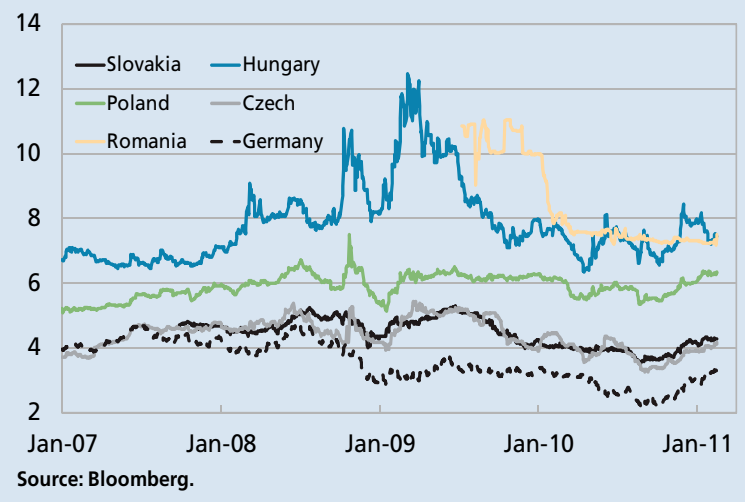




\section{FINANCIAL SECTOR-ADVANCING THE FINANCIAL} SECTOR WHILE ENHANCING SAFEGUARDS

The financial sector has strengthened and banks enhanced their balance sheets. However, similar to other CE4 countries, the financial sector is relatively underdeveloped, and dominated by banks. The key is to enhance safeguards to buttress the banking system, and take measures to encourage further development of the financial sector.

\section{Background}

\section{The financial sector is dominated by} foreign-owned banks (see Annex II). The banking sector accounts for almost three quarters of all assets owned or managed by the financial sector. All banks, except two small ones, are controlled by foreigners through subsidiaries or foreign branches.

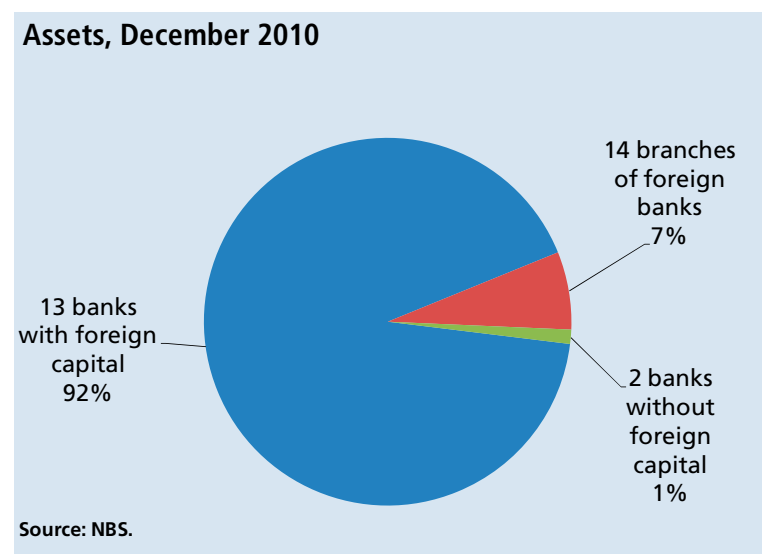

37. Banks' soundness and profits have improved with the resurgence of economic activity. A traditional banking model with little reliance on wholesale funding and limited investment in foreign securities helped banks withstand the global financial crisis. Nonetheless, during 2009 nonperforming loans surged and profits declined significantly before recovering in
2010. The rebound in profits, driven by cost cutting measures, higher net interest income and lower provisions, allowed banks to increase capital and liquidity ratios-regulatory capital was about 13 percent, and (core) tier 1 capital 11 percent in 2010. Furthermore, recent stress tests carried out by the central bank suggest that the banks can withstand severe shocks to output and inflation.

38. Nevertheless, risks remain. Nonperforming loans, particularly to the corporate sector, are still high, even though they started to decrease in the last quarter of 2010. Residential property prices have stabilized, but the commercial real estate and construction sectors remain a source of concern. Furthermore, even though banks have limited direct exposure to foreign securities, they could still be affected through the impact on their parent banks in case of renewed sovereign risk pressures in the euro area. Finally, a large share of the banks' securities portfolio is in Slovak government bonds. While these bonds are low risk assets, a large concentration, in general, is a source of concern. 


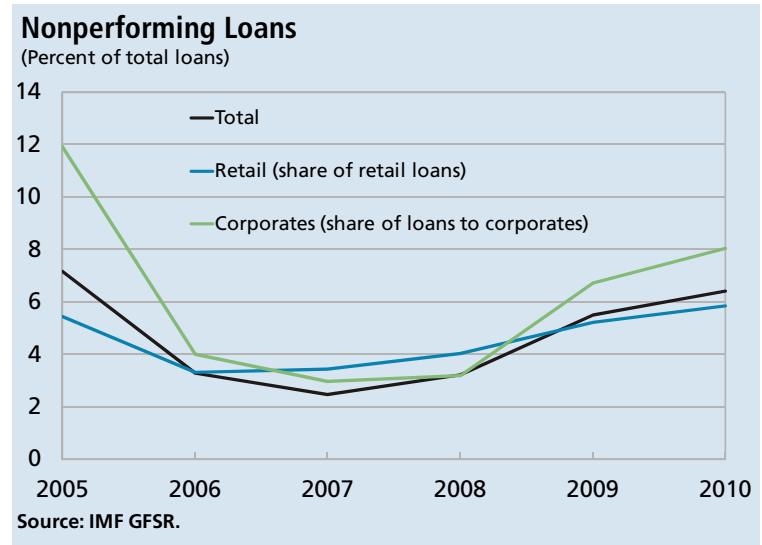

\section{Staff's Views}

39. Strengthening supervision is essential, particularly with respect to cross border risks.

As foreign parents banks can still withdraw liquidity, albeit within strict limits, and exchange assets with their domestic subsidiaries, it is important to monitor risks affecting parent banks and to continue to strengthen synergies with the European Banking Authority and home supervisors of parent banks. In addition, it is essential to remain vigilant to prevent excessive risk taking and credit growth, which is particularly costly to unwind as the experience of some earlier euro adopters vividly illustrates.

\section{Particular attention should be devoted}

to the mortgage market. Tougher competition since the second half of 2010 has led to a reduction in lending rates, which are gradually converging towards the average in the euro area. At the same time, the share of new loans with loan-to-value ratios above 80 percent has significantly increased in 2010, from 34 to 43 percent. Furthermore, banks have substituted traditional mortgages with other housing loans that are subject to weaker regulations with regard to loan-to-value ratios and the requirement to issue mortgage bonds. An additional source of concern is the nontransparent pricing of housing loans which allows banks to adjust rates at their full discretion after the fixation period.
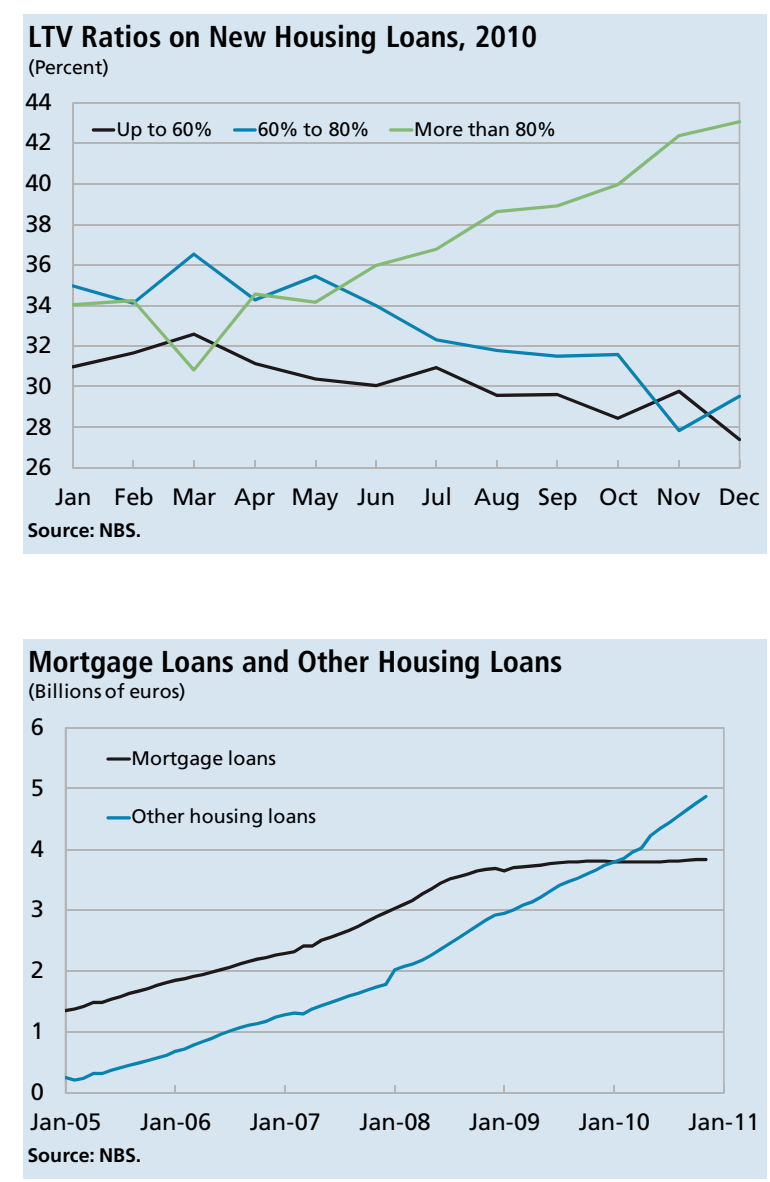

41. Harmonizing regulations on all housing loans would ensure that regulation aimed at limiting excessive risk taking remains effective. In addition, steps to increase the transparency of mortgage loans with regard to interest rate adjustments would improve consumer protection.

42. While generally sound, the financial system is still relatively underdeveloped. The 
equity market is small, a private bond market is non-existent, and the secondary government bond market is thin. While short-term liquidity for government bonds is ensured by the ECB repo refinancing, banks have to rely largely on over-thecounter transactions to adjust their positions. Furthermore, the share of banks' assets to GDP at the end of 2009 was slightly above 80 percent, compared to averages of 110 percent in the other CE4 countries and 265 percent in the euro area.

43. Investment restrictions on Pillar II pension funds are too tight. In particular, the guarantees of positive returns and low mandated management fees should be adjusted. These restrictions cause Pillar II pension funds to invest exclusively in safe and liquid assets, such as shortterm government bonds and bank deposits. This limits investment choices for households that could prefer a portfolio with longer horizon or higher risk and hinders the development of domestic securities markets.

\section{Authorities' Views}

44. The banking sector is sound and well positioned to meet Basel III criteria. The improvement in capitalization and profitability has considerably strengthened the banking sector and stress tests reveal strong resilience even to significant GDP and inflation shocks, including a drop in GDP of 6 percent and a jump in inflation to 8 percent. Basel III capital and liquidity criteria should be met fairly comfortably within the proposed time frame, since the ratios are already around the Basel III 2019 proposed levels. The NBS coordinates supervision at the EU level through the colleges of supervisors. In any case, national supervisors should retain strong supervisory powers, given that the costs to support local financial markets in circumstances of distress fall upon the national authorities.

\section{Credit growth and lending conditions are closely monitored and regulatory harmonization of housing loans is being} considered. Intensifying competition from small banks against a background of an improving economic environment has reduced borrowing costs. The bank supervisor is paying close attention to the increase in loan-to-value ratios on new loans, the move towards less regulated other housing loans, and early indicators of a possible credit boom more in general. To limit risks, a more homogenous regulation of all housing loans is considered, as well as measures to increase transparency on the pricing of mortgage.

46. Efforts to enhance financial development are being considered. The debt management agency has taken steps to increase the liquidity in the secondary market for government bonds by increasing issuance size and focusing on benchmark instruments. Furthermore, liquidity would benefit from the planned implementation of a primary dealers system. With regard to Pillar II pension funds, proposals to reform the system, including easing investment restrictions, are being discussed with all political parties to seek a broad consensus which would ensure sustainability. 


\section{Figure 4 Slovak Republic-Financial Indicators, 2005-10}

The financial system is dominated by (foreign-owned) banks...

Assets, June 2010

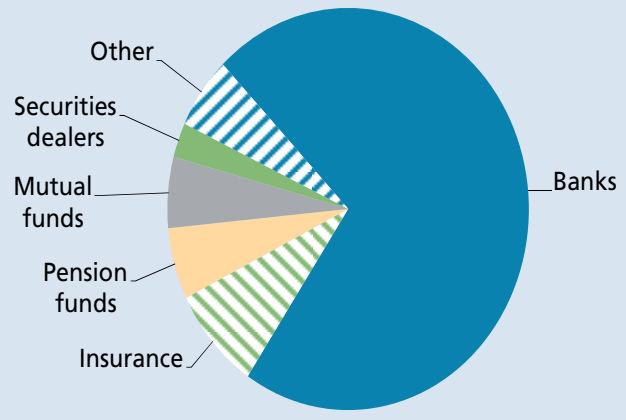

Source: NBS.

Banks' assets are mostly domestic loans and government bonds...

Assets, September 2010

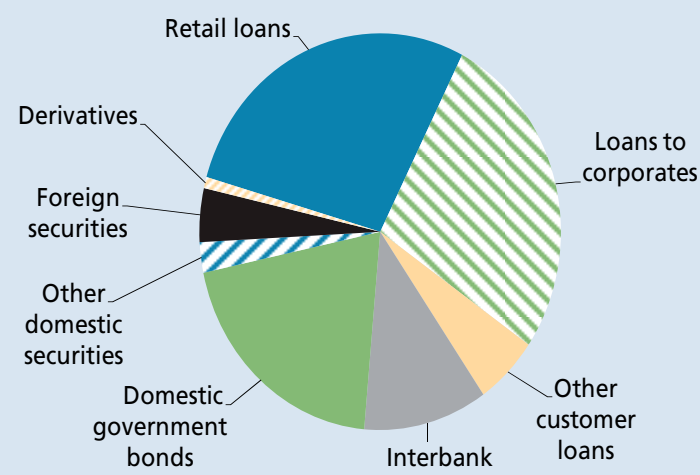

Source: NBS.

\section{Banks' profitability dropped in 2009, but rebounded in} 2010...

Return on Assets

(Percent)

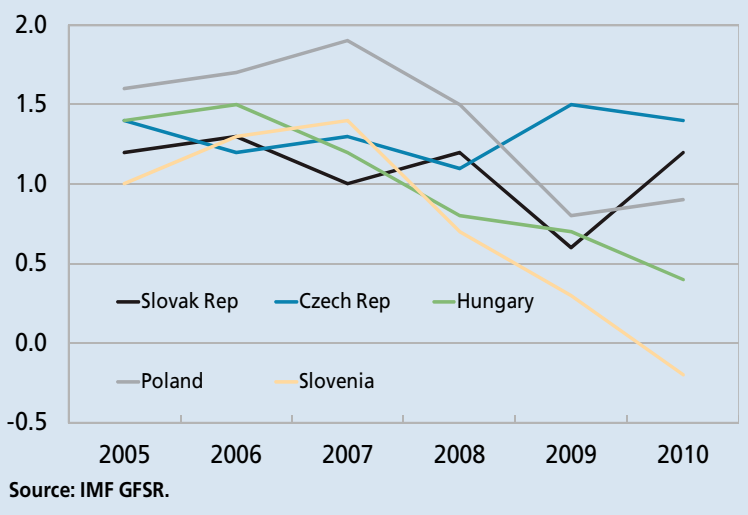

... whose size relative to GDP is still below comparator countries.

Banks' Assets, 2009

(Percent of GDP)

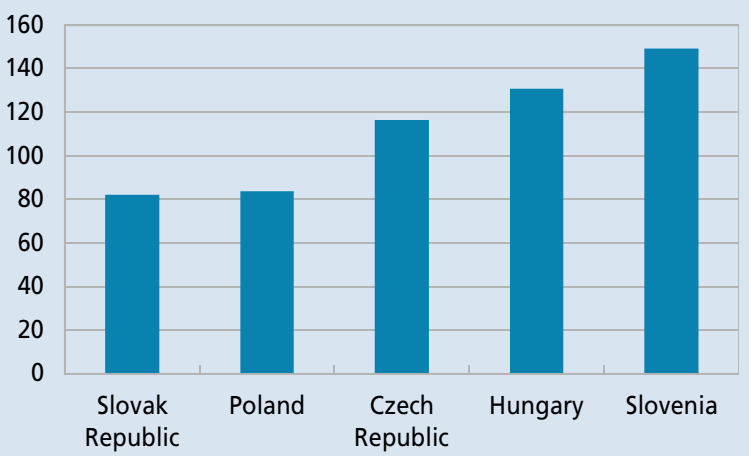

Source: Raffeisen

... while liabilities are primarily from deposits.

Liabilities, September 2010

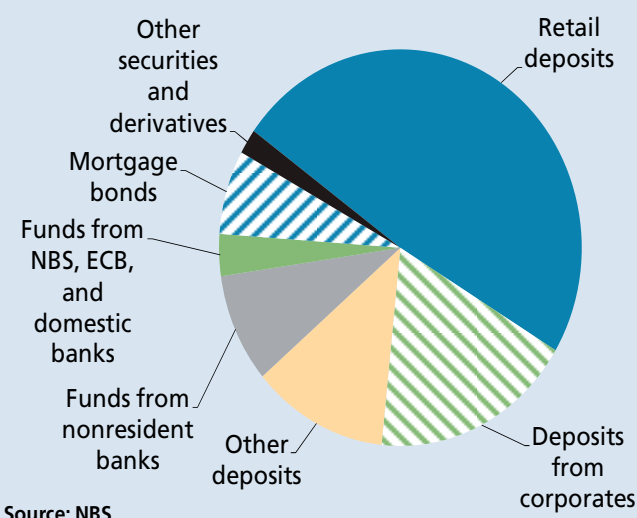

\section{...and capitalization has improved.}

Regulatory Capital to Risk-Weighted Assets (Percent)

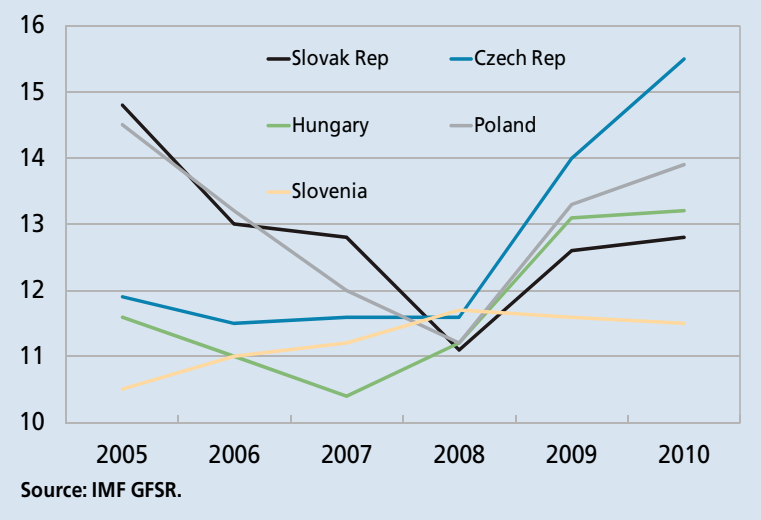


Box $3 . \quad$ Sovereign Bonds Yields

Slovak government bonds performed overall well during the global financial turmoil. In the fall of 2008 reflecting broad concerns about the financial sector in the euro area, the spread on the 10-year German Bund increased considerably. However, the economic recovery in the second half of 2009 and the government commitment to fiscal consolidation led to a gradual reduction in spreads to about 1 percentage point. With reference to CE4 countries, spreads on Slovak government bonds are similar to the Czech Republic, substantially below Hungary and Poland.

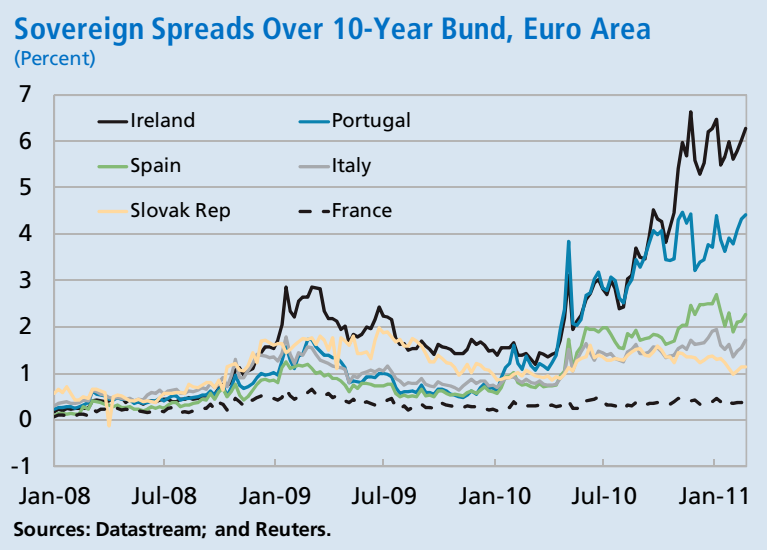

Sovereign Spreads Over 10-Year Bund, CE4 (Percent)

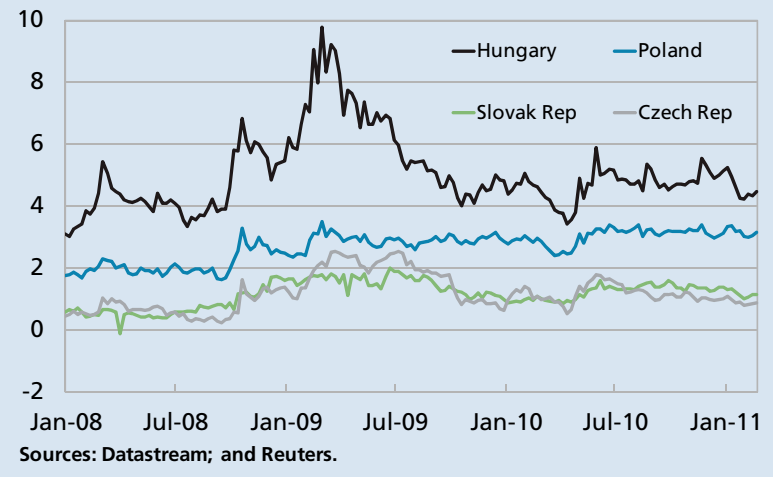

Several factors explain this relatively low spread. Public debt remains relatively low at 41 percent of GDP, even though it has grown considerably since 2008. The government's commitment to fiscal consolidation has preserved market confidence although the fiscal deficit has increased to almost 8 percent of GDP. The rebound in economic growth improved debt dynamics. Finally, the adoption of the euro in January of 2009 eliminated currency risks and supported the liquidity of Slovak government bonds through the ECB operations.

Nevertheless, conditional on fundamentals the yields on Slovak sovereign bonds are still significantly above other euro countries. A regression analysis based on 11 euro countries (Austria, Belgium, Finland, France, Germany, Greece, Ireland, Italy, the Netherlands, Portugal, and Spain) reveals that yields are positively correlated with government debt and the fiscal deficit as a percentage of GDP, and negatively correlated with real GDP growth and government bond liquidity (captured by the stock of government debt). The plot below compares the average yields in 2010 with the predicted yields. The average yields on Slovak government bonds have been considerably above the predicted values, similarly to other CE4 countries outside the euro area. This suggests that Slovak yields have benefited from strong fundamentals, but some premium above core euro area still remains.

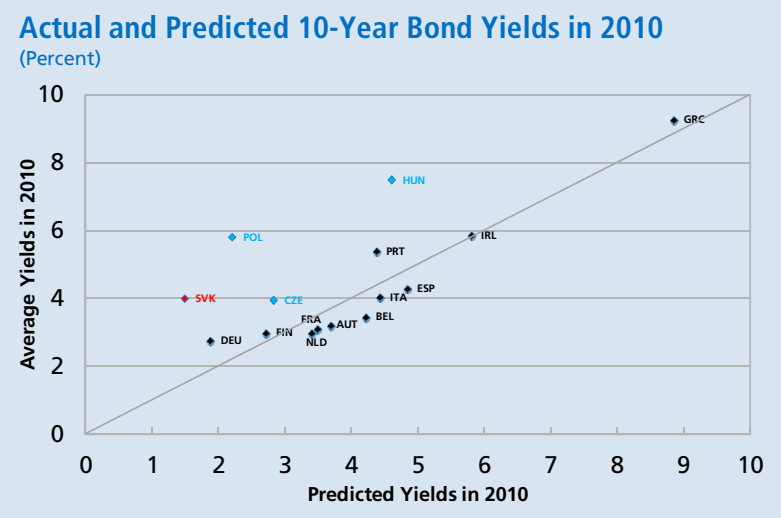

Sources: Datastream; Reuters; and IMF staff estimates.

Developing domestic financial markets and solidifying credibility would further reduce spreads. Deepening secondary markets for government bonds by introducing market makers and relaxing regulations on Pillar II pension funds would increase liquidity and lower spreads. In addition, establishing a credible medium-term fiscal consolidation path would enhance credibility and bring spreads in line with core euro countries. 


\section{STRUCTURAL POLICY－TACKLING UNEMPLOYMENT} AND REGIONAL DISPERSION

The crisis caused the already high unemployment to surge, and long-term unemployment of low-skilled and young workers has risen to among the highest in the EU. Moreover, regional dispersion in employment and income is large. Tackling theses issues is essential and will require a range of policies and long-lasting efforts.

\section{Background}

47. An already high pre-crisis unemployment rate has soared to over 14 percent. The unemployment rate, which is among the highest in the EU, is of a particular concern because long-term unemployment among low-skilled workers and youth is exceptionally high. In early 2011, more than one out of three workers under 25 was unemployed, and the long-term unemployment rate, at 9.5 percent, was the worst in the EU. Regretfully, the economic recovery and incipient rebound in overall employment have yet to translate in improved prospects for the long-term unemployed.

48. Furthermore, there is large divergence among regions in terms of economic developments, education and employment. In 2008, GDP per inhabitant in the Bratislava region was almost three times the level in the two poorest regions, which were more than 40 percent below the EU27 average. With regard to unemployment, the regional dispersion is even more pronounced.

49. The authorities plan several steps to bring down unemployment. They propose, among other initiatives, to link part of social benefits for the unemployed to training and job search efforts, and to expand the intermediate labor market. ${ }^{2}$ More broadly, the authorities intend to amend the Labor Code with a view to reducing administrative burdens, minimizing hiring and firing costs, and enhancing the flexibility of wage negotiations. At the same time they would like to strengthen the protection of the most vulnerable workers.

\section{Staff's Views}

50. The high long-term unemployment and the regional dispersion reflect a range of factors and will require a menu of policy actions. Long-term unemployment was already high before the crisis due to structural problems, including low skills, limited labor mobility, and weak work incentives. Firms sharply cut employment when the crisis hit and used productivity gains to increase output during the recovery, further driving up long-term unemployment. To be successful, the new initiatives announced by the authorities need

\footnotetext{
2 These include subsidizing temporary employment opportunities that combine paid work with tailored preparation for the open labor market.
} 
to be fully implemented and properly funded. In addition, the authorities should make wide-ranging and sustained efforts to enhance existing labor market policies, notably by focusing more on training, and to strengthen implementation and program evaluation capacity. Sharpening the orientation of education and vocational programs towards labor market needs, with a focus on high unemployment regions, should also be on the agenda. Differentiating the minimum wage among regions according to cost of living could help strengthen employment incentives. Improving the transport infrastructure and fostering the development of a private rental market could help ease labor mobility constraints.

51. Productivity gains are the main driver of medium-term growth potential and convergence, and the key to maintaining external competitiveness. Sustained efforts to build and enhance human capital, further improve the business environment and foster competition, notably in network industries, will help boost productivity. To maintain the strong performance of Slovakia's main export sectors, productivity gains in combination with labor market flexibility and wage growth moderation, particularly in light of the increase in inflation, should help avoid unfavorable unit labor cost developments relative to those abroad.

52. Efforts to improve the business environment should focus on public sector governance and legal enforcement. Business environment surveys continue to show concern about corruption, which is seen as among the most severe impediments to doing business in Slovakia. They also note delays and uncertainties in enforcing legal claims. The authorities have introduced welcome measures to improve the transparency of public procurement, but more may need to be done.

\section{Authorities' Views}

53. There is an urgent need to tackle the high unemployment challenge. The recently announced active labor market policy initiatives, an increase in labor market flexibility, and the resumption of steady and robust growth will all contribute to a significant reduction in long-term unemployment, albeit slowly.

54. The new government sees strengthening public sector governance as one of its key priorities. New measures to improve the transparency of public procurement include the compulsory use of electronic auctions for public procurement and the publication of the terms of the contract and the successful bidder. These measures already are having a positive impact, and will be complemented and expanded with other steps as needed. 


\section{Figure 5 Slovak Republic-Labor Market Indicators, 2004-10}

\section{Unemployment stabilized at a high rate.}

Unemployment Rate
(Percent, seasonally-adjusted)

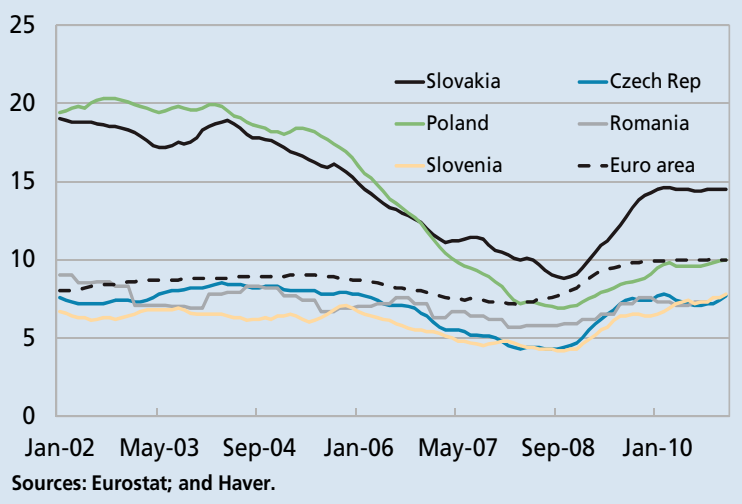

\section{...as well as youth unemployment.}

Unemployment by Age

(Percent)

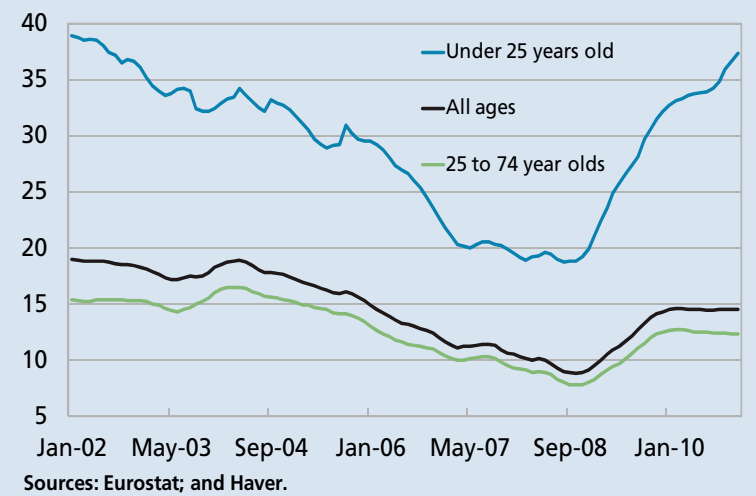

...caused by a drop in employment in the manufacturing sector...

Employment by Sector

(Thousands)

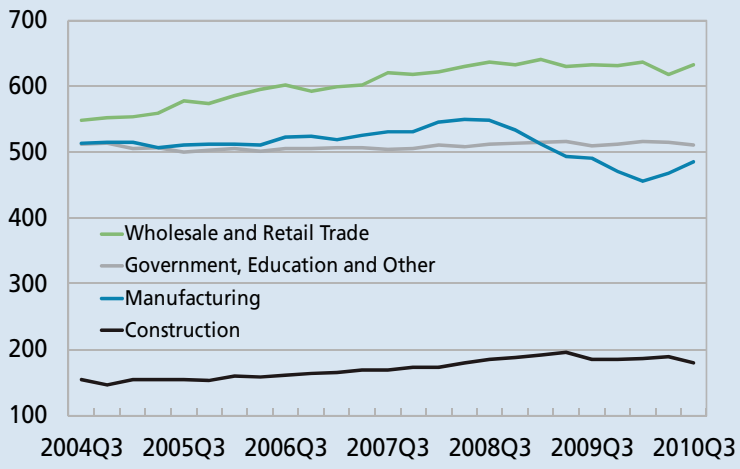

Sources: Eurostat; and Haver.
Long-term unemployment is high and growing...

Long-Term Unemployment

(Percent of total unemployment)

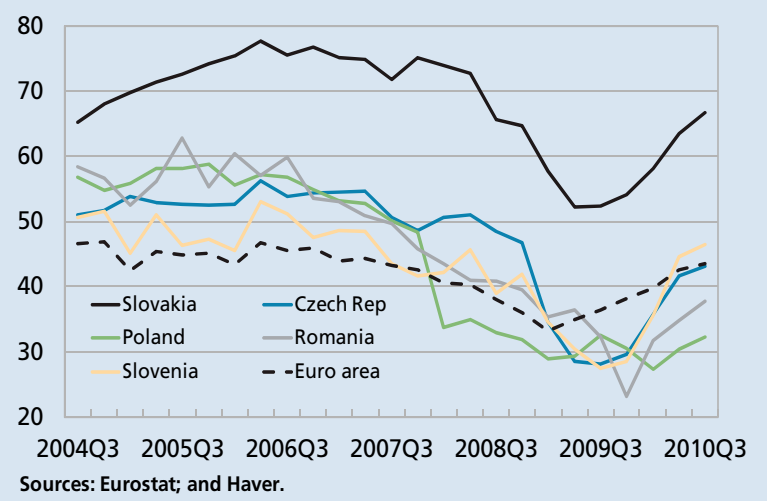

Employment dropped faster compared to other countries in the region...

Employment

(2005=100)

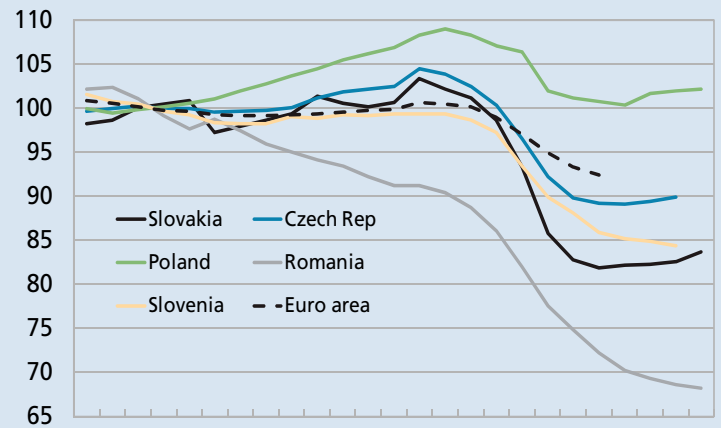

2004Q4 2005Q4 2006Q4 2007Q4 2008Q4 2009Q4 2010Q4 Sources: Eurostat; and Haver.

... While labor participation has remained relatively low.

Labor Force Participation Rates

(Percent)

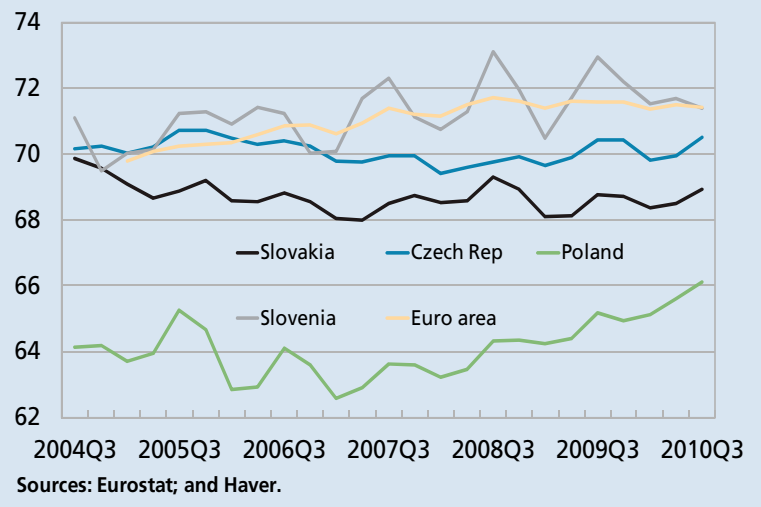




\section{STAFF APPRAISAL}

56. Following a deep but relatively short recession, economic conditions and prospects have turned favorable, with real GDP growth stabilizing at around 4 percent per annum. The financial sector has regained strength, profits in the corporate sector are recovering, real estate prices have stabilized, and the fiscal position is improving. However, long-term unemployment remains very high, and considerable downside risks to the outlook, both domestic and external, are elevated.

57. The favorable outlook shifts the policy focus to enhancing the foundations for long term growth and stability while addressing the crisis-induced deterioration in the fiscal position. Productivity gains will be the key to maintaining robust growth and, in combination with labor market flexibility and wage moderation, safeguarding external competitiveness. Incipient signs of a credit boom that could threaten the hardwon stability should be carefully monitored. And fiscal policy should aim at regaining strong footing while advancing growth-enhancing expenditure and tax priorities.

58. The size and composition of the $\mathbf{2 0 1 1}$ consolidation effort are broadly appropriate. The government deficit is projected to drop below 5 percent of GDP this year, as targeted.

59. The authorities' commitment to further reduce the deficit to below 3 percent of GDP by 2013 is credible and appropriate. Pacing the adjustment evenly in 2012-13 will help minimize the negative impact on growth.
60. Achieving the $\mathbf{2 0 1 3}$ deficit target will be challenging and require careful consideration of evolving expenditure and tax priorities and the quality of the adjustment. There is no room for premature tax cuts or for additional spending without re-prioritization. Concentrating the consolidation effort on some minor taxes and on further cutting government wages and operational costs is unlikely to be a viable strategy, and may erode some essential government services to unsustainably low levels.

61. The authorities' initiatives to pursue important fiscal institutional reforms are welcome. Harmonizing and simplifying social security contributions and unifying revenue collection are important steps toward efficient and transparent revenue collection. The introduction of fiscal rules, a fiscal council and mechanisms to strengthen local public finances are expected to improve commitment, discipline, transparency and planning. The efforts to seek a broad consensus on the key reforms are very laudable.

62. The proposed actions to improve the long-term prospects of the pension system are appropriate. In particular, plans to automatically align the retirement age with changes in life expectancy and the old age dependency ratio and to adjust indexation formulas could help ensure the viability of the first pillar pension system.

63. Financial sector conditions have strengthened further with the improvement in the economic environment. Financial soundness 
indicators are solid, and recent stress tests carried out by the National Bank of Slovakia reassure that banks can cope with severe shocks to economic growth and inflation.

64. Nevertheless, risks remain and continued vigilance is needed. Indications of an unwarranted easing of lending conditions or acceleration of credit growth will need to be carefully monitored. The authorities should also harmonize the different treatment of housing loans to ensure that regulation aimed at limiting excessive risk taking remains effective.

65. Deepening the secondary government bond market could contribute to broader capital market development. Steps taken by the debt management agency to increase issuance size and focus on benchmark instruments are welcome. Relaxing the restrictions on investment policies of the second pillar pension funds would also benefit the capital market, and would help align the objectives and horizons of savers with their investment.

66. In the wake of the crisis, addressing long-term unemployment and regional disparities is even more pressing. Bringing down long-term unemployment will require a range of measures. In this regard, various new initiatives considered by the authorities are encouraging. They need to be complemented with efforts to enhance existing active labor market policies and require appropriate funding as well as careful program evaluation.

67. It is recommended that the next Article IV consultation take place on the standard 12month cycle. 


\begin{tabular}{|c|c|c|c|c|c|c|c|c|c|c|}
\hline \multicolumn{11}{|l|}{ (As percent of World GDP) } \\
\hline & \multirow[b]{2}{*}{2006} & \multirow[b]{2}{*}{2007} & \multirow[b]{2}{*}{2008} & \multirow[b]{2}{*}{2009} & \multicolumn{6}{|c|}{ Projections } \\
\hline & & & & & 2010 & 2011 & 2012 & 2013 & 2014 & 2015 \\
\hline & \multicolumn{10}{|c|}{ (Annual percentage change, constant prices, unless noted otherwise) } \\
\hline Real GDP & 8.5 & 10.5 & 5.8 & -4.8 & 4.0 & 3.8 & 4.2 & 4.3 & 4.2 & 4.2 \\
\hline Domestic demand & 6.6 & 6.4 & 5.7 & -7.9 & 2.7 & 1.8 & 3.6 & 3.9 & 4.0 & 4.0 \\
\hline Public consumption & 9.7 & 0.1 & 6.1 & 5.6 & 0.1 & 0.2 & 1.7 & 2.0 & 2.0 & 2.1 \\
\hline Private consumption & 5.9 & 6.8 & 6.2 & 0.3 & -0.3 & 2.3 & 3.8 & 4.1 & 4.0 & 4.0 \\
\hline Gross capital formation & 6.1 & 9.7 & 4.7 & -31.0 & 12.9 & 1.7 & 4.7 & 5.0 & 5.4 & 5.3 \\
\hline Net exports (contributions to growth) & 2.1 & 4.7 & 0.1 & 2.0 & 2.1 & 1.5 & 0.8 & 0.7 & 0.6 & 0.6 \\
\hline Exports of goods and services & 21.0 & 14.3 & 3.1 & -15.9 & 16.4 & 8.5 & 6.6 & 6.0 & 5.7 & 5.5 \\
\hline Imports of goods and services & 17.8 & 9.2 & 3.1 & -18.6 & 14.9 & 7.5 & 6.3 & 5.8 & 5.6 & 5.4 \\
\hline \multicolumn{11}{|l|}{ Prices } \\
\hline Inflation (CPI) & 4.3 & 1.9 & 3.9 & 0.9 & 0.7 & 3.4 & 2.7 & 2.9 & 2.8 & 2.8 \\
\hline Inflation (CPI, end of period) & 3.5 & 2.4 & 3.5 & 0.1 & 1.3 & 3.4 & 2.9 & 2.8 & 2.8 & 2.8 \\
\hline \multicolumn{11}{|l|}{ Employment and wages } \\
\hline Employment & 3.8 & 2.4 & 3.2 & -2.8 & -2.1 & 1.9 & 1.6 & 1.5 & 1.3 & 1.0 \\
\hline Nominal wages & 6.7 & 6.4 & 7.6 & 2.4 & 5.4 & 4.0 & 6.5 & 6.0 & 6.0 & 6.0 \\
\hline \multirow[t]{2}{*}{ Unemployment rate (percent) } & 13.3 & 11.0 & 9.6 & 12.1 & 14.4 & 13.3 & 12.1 & 11.1 & 10.1 & 9.4 \\
\hline & \multicolumn{10}{|c|}{ (Percent of GDP) } \\
\hline \multicolumn{11}{|l|}{ Public Finance, General Government } \\
\hline Revenue & 33.4 & 32.5 & 32.9 & 33.6 & 33.1 & 33.1 & 32.7 & 32.7 & 32.7 & 32.3 \\
\hline Expenditure & 36.6 & 34.3 & 35.0 & 41.5 & 40.9 & 37.9 & 36.3 & 35.7 & 34.8 & 33.7 \\
\hline Overall balance & -3.2 & -1.8 & -2.1 & -7.9 & -7.8 & -4.9 & -3.7 & -3.0 & -2.1 & -1.4 \\
\hline Primary balance & -1.7 & -0.4 & -0.8 & -6.5 & -6.4 & -3.2 & -1.9 & -1.0 & -0.1 & 0.7 \\
\hline Structural balance (percent of potential GDP) & -3.6 & -2.5 & -2.6 & -6.4 & -7.0 & -4.5 & -3.5 & -2.7 & -2.8 & -2.4 \\
\hline \multirow[t]{2}{*}{ General government debt } & 30.5 & 29.6 & 27.8 & 35.4 & 41.7 & 44.4 & 45.4 & 45.8 & 45.4 & 46.0 \\
\hline & \multicolumn{10}{|c|}{ (Percent) } \\
\hline \multicolumn{11}{|l|}{ Monetary and financial indicators } \\
\hline Bank credit to private sector (growth rate) 1/ & 23.9 & 22.2 & 15.6 & 1.0 & 3.4 & & & & & \\
\hline Lending rates $2 /$ & 9.2 & 9.3 & 8.1 & 6.9 & 6.8 & & & & & \\
\hline Deposit rates 3/ & 0.9 & 0.8 & 0.7 & 0.3 & 0.2 & & & & & \\
\hline \multirow[t]{2}{*}{ Government 10-year bond yield } & 4.4 & 4.5 & 4.7 & 4.7 & 3.9 & & & & & \\
\hline & \multicolumn{10}{|c|}{ (Percent of GDP) } \\
\hline \multicolumn{11}{|l|}{ Balance of payments } \\
\hline Trade balance (goods) & -4.7 & -1.2 & -1.1 & 1.9 & 0.8 & 0.6 & 0.5 & 0.6 & 0.5 & 0.6 \\
\hline Current account balance & -7.8 & -5.3 & -6.6 & -3.6 & -3.4 & -2.8 & -2.7 & -2.6 & -2.7 & -2.6 \\
\hline Gross external debt & 51.0 & 54.5 & 56.3 & 71.9 & 72.1 & 70.4 & 67.8 & 65.2 & 63.1 & 60.6 \\
\hline \multicolumn{11}{|c|}{ Sources: National Authorities; and IMF staff calculations. } \\
\hline \multicolumn{11}{|c|}{ 1/ Last data point 30 September 2010} \\
\hline 2/ Loans of up to one year, non-housing new lo & to ne & usehol & & & & & & & & \\
\hline
\end{tabular}




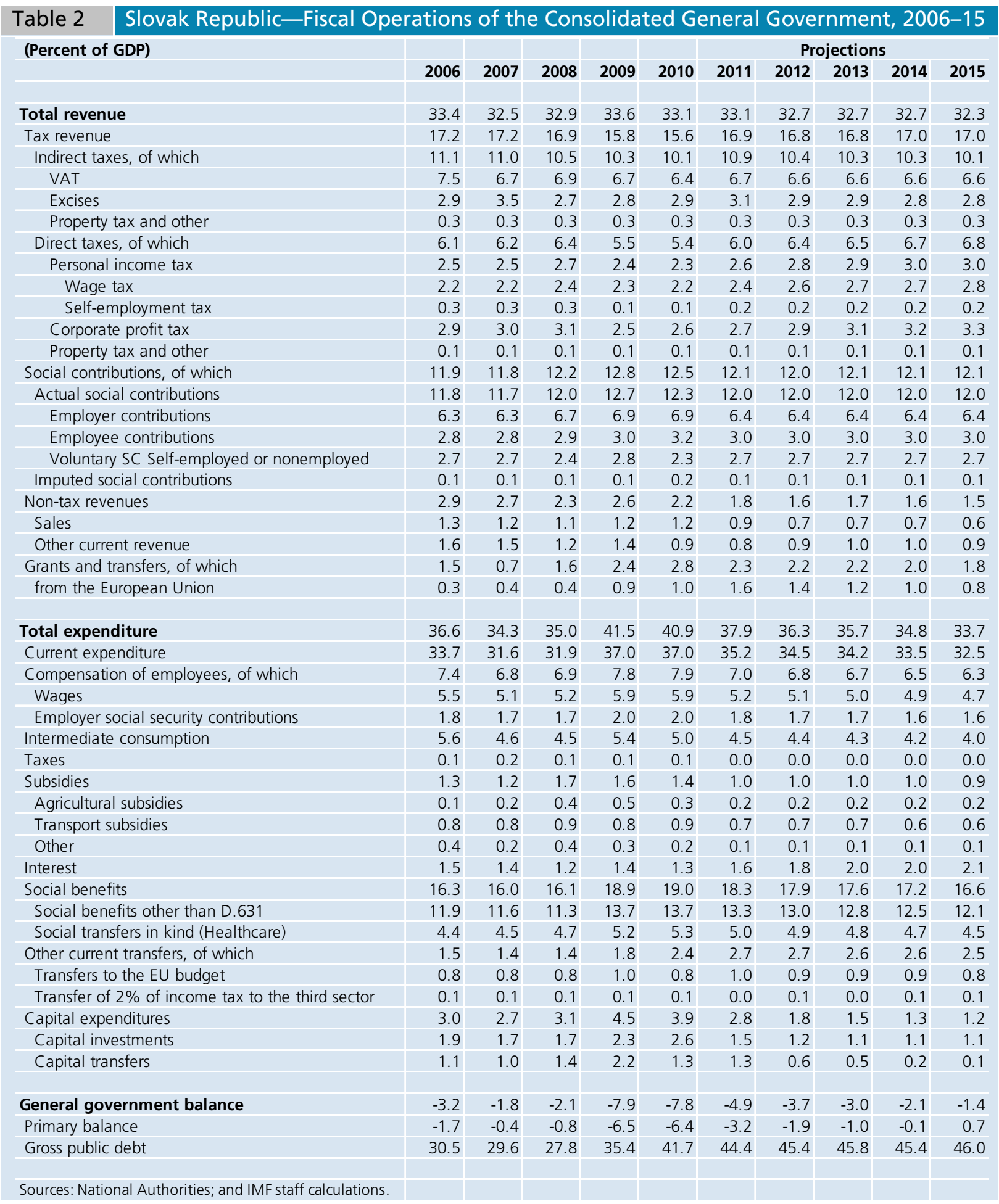


Table 3 Slovak Republic-Medium-Term Balance of Payments, 2006-15

(In millions of euros, unless otherwise indicated)

\begin{tabular}{|c|c|c|c|c|c|c|c|c|c|c|}
\hline & & & & & \multicolumn{6}{|c|}{ Projections } \\
\hline & 2006 & 2007 & 2008 & 2009 & 2010 & 2011 & 2012 & 2013 & 2014 & 2015 \\
\hline Current account balance & $-4,316$ & $-3,240$ & $-4,433$ & $-2,264$ & $-2,271$ & $-1,970$ & $-2,024$ & $-2,002$ & $-2,205$ & $-2,300$ \\
\hline Trade balance (goods) & $-2,562$ & -725 & -758 & 1,187 & 509 & 417 & 374 & 431 & 456 & 564 \\
\hline Exports, f.o.b. & 40,892 & 47,351 & 49,522 & 39,716 & 48,794 & 55,158 & 60,383 & 65,398 & 70,254 & 75,632 \\
\hline Imports, f.o.b. & $-43,454$ & $-48,076$ & $-50,280$ & $-38,529$ & $-48,285$ & $-54,741$ & $-60,009$ & $-64,967$ & $-69,798$ & $-75,068$ \\
\hline Services balance & 727 & 424 & -457 & $-1,244$ & -680 & -637 & -708 & -763 & -821 & -874 \\
\hline Receipts & 5,311 & 5,743 & 5,999 & 4,518 & 4,500 & 6,129 & 6,709 & 7,266 & 7,806 & 8,404 \\
\hline Payments & $-4,584$ & $-5,319$ & $-6,456$ & $-5,762$ & $-5,180$ & $-6,766$ & $-7,417$ & $-8,030$ & $-8,627$ & $-9,278$ \\
\hline Income balance & $-2,427$ & $-2,571$ & $-2,325$ & $-1,531$ & $-2,400$ & $-2,450$ & $-2,450$ & $-2,450$ & $-2,700$ & $-2,850$ \\
\hline Receipts & 2,026 & 1,989 & 2,393 & 1,970 & 1,900 & 2,150 & 2,200 & 2,250 & 2,300 & 2,350 \\
\hline Payments & $-4,472$ & $-4,571$ & $-4,688$ & $-3,258$ & $-4,300$ & $-4,600$ & $-4,650$ & $-4,700$ & $-5,000$ & $-5,200$ \\
\hline Current transfers & -54 & -368 & -893 & -676 & 300 & 700 & 760 & 780 & 860 & 860 \\
\hline Capital and financial account balance & 1,450 & 6,245 & 5,946 & 3,422 & 2,271 & 1,970 & 2,024 & 2,002 & 2,205 & 2,300 \\
\hline Capital account & -40 & 377 & 806 & 464 & 484 & 504 & 524 & 544 & 564 & 584 \\
\hline Direct foreign investment & 4,122 & 2,444 & 2,236 & -347 & 1,175 & 1,657 & 2,136 & 2,213 & 2,291 & 2,363 \\
\hline Reinvested earnings & 933 & 586 & 558 & 499 & & & & & & \\
\hline Portfolio investment & 1,601 & -585 & 1,671 & -928 & 500 & 530 & 560 & 590 & 620 & 650 \\
\hline Other investment & $-4,073$ & 3,961 & 1,352 & 3,967 & 112 & -721 & $-1,196$ & $-1,346$ & $-1,270$ & $-1,297$ \\
\hline Reserve assets $1 /$ & 2,592 & $-3,186$ & 113 & 567 & $\ldots$ & $\ldots$ & $\ldots$ & $\ldots$ & $\ldots$ & $\ldots$ \\
\hline Errors and omissions & 2,866 & $-3,005$ & $-1,436$ & $-1,158$ & $\ldots$ & $\ldots$ & $\ldots$ & $\ldots$ & $\ldots$ & $\ldots$ \\
\hline Overall balance & $-2,592$ & 3,186 & -113 & -567 & $\ldots$ & $\ldots$ & $\ldots$ & $\ldots$ & $\ldots$ & $\ldots$ \\
\hline Financing & 2,592 & $-3,186$ & 113 & 567 & $\ldots$ & $\ldots$ & $\ldots$ & $\ldots$ & $\ldots$ & $\ldots$ \\
\hline Gross reserves (negative indicates increase) & 2,592 & $-3,186$ & 113 & 567 & $\ldots$ & $\ldots$ & $\ldots$ & $\ldots$ & $\ldots$ & $\ldots$ \\
\hline Memorandum items: & & & In percent & $\mathrm{t}$ of GDP, & unless oth & herwise in & ndicated) & & & \\
\hline Current account balance & -7.8 & -5.3 & -6.6 & -3.6 & -3.4 & -2.8 & -2.7 & -2.6 & -2.7 & -2.6 \\
\hline Trade balance (G\&NFS) & -3.3 & -0.5 & -1.8 & -0.1 & -0.3 & -0.3 & -0.5 & -0.4 & -0.4 & -0.4 \\
\hline Merchandise export volume (percent change) & 22.1 & 15.1 & 3.6 & -15.2 & 18.8 & 8.5 & 6.6 & 6.0 & 5.7 & 5.5 \\
\hline Value (percent change) & 23.5 & 14.9 & 4.6 & -20.3 & 20.5 & 15.0 & 9.5 & 8.3 & 7.4 & 7.7 \\
\hline Merchandise import volume (percent change) & 19.0 & 8.6 & 1.5 & -19.5 & 19.0 & 7.5 & 6.3 & 5.8 & 5.6 & 5.4 \\
\hline Terms of trade (percent change from previous year) & -5.0 & -2.7 & -6.0 & 5.5 & & & & & & \\
\hline Income balance & -4.4 & -4.2 & -3.5 & -2.4 & -3.6 & -3.5 & -3.3 & -3.1 & -3.3 & -3.2 \\
\hline Current transfers & -0.1 & -0.6 & -1.3 & -1.1 & 0.5 & 1.0 & 1.0 & 1.0 & 1.0 & 1.0 \\
\hline Total external debt (billion euros) & 24.5 & 30.1 & 37.7 & 45.3 & 47.5 & 49.0 & 50.1 & 51.1 & 52.4 & 53.7 \\
\hline Total external debt (in percent of GDP) & 51.0 & 54.5 & 56.3 & 71.9 & 72.1 & 70.4 & 67.8 & 65.2 & 63.1 & 60.6 \\
\hline GDP (euro millions) & 55,081 & 61,555 & 67,007 & 63,050 & 65,906 & 69,532 & 73,898 & 78,391 & 82,954 & 88,565 \\
\hline
\end{tabular}




\begin{tabular}{|c|c|c|c|}
\hline Slovak Republic_Financial Soundness Indicato & he Ba & S Sectc & $008-10$ \\
\hline (In percent, unless otherwise indicated) & & & \\
\hline & 2008 & 2009 & Mar-10 \\
\hline Capital Adequacy & & & \\
\hline Regulatory capital to risk-weighted assets & 11.1 & 12.6 & 12.7 \\
\hline Regulatory Tier 1 capital to risk-weighted assets & 10.7 & 11.4 & 11.5 \\
\hline Capital to assets & 8.2 & 9.6 & 9.7 \\
\hline Asset Composition and Quality & & & \\
\hline Nonperforming loans to gross loans & 2.5 & 5.3 & 5.8 \\
\hline Nonperforming loans net of provisions to capital & 6.7 & 14.3 & 15.7 \\
\hline Customer deposits to total (noninterbank) loans & 98.9 & 117.3 & 115.4 \\
\hline Earnings and Profitability & & & \\
\hline Return on assets (after tax) & 1.2 & 0.6 & 1.1 \\
\hline Return on equity (after tax) & 15.4 & 6.7 & 11.5 \\
\hline Interest margin to gross income & 65.9 & 76.8 & 73.8 \\
\hline Noninterest expenses to gross income & 57.3 & 62.3 & 55.7 \\
\hline Liquidity & & & \\
\hline Liquid assets to total assets & 52.1 & 43.4 & 41.8 \\
\hline Liquid assets to short-term liabilities & 65.0 & 57.3 & 57.9 \\
\hline Sectoral distribution of loans to total loans & & & \\
\hline Residents & 95.6 & 93.4 & 93.8 \\
\hline Deposit-takers & 0.3 & 0.1 & 0.1 \\
\hline Central bank & 22.2 & 0.0 & 0.0 \\
\hline Other financial corporations & 4.6 & 4.2 & 3.5 \\
\hline General government & 1.9 & 2.6 & 2.6 \\
\hline Nonfinancial corporations & 36.1 & 44.1 & 44.3 \\
\hline Other domestic sectors & 30.5 & 42.5 & 43.3 \\
\hline Nonresidents & 4.4 & 6.6 & 6.2 \\
\hline Geographical distribution of loans to total loans & & & \\
\hline Domestic economy & 97.4 & 95.6 & 96.1 \\
\hline Advanced economies, excluding China & & & \\
\hline Other emerging market and developing countries, including China & 2.6 & 4.4 & 3.9 \\
\hline Africa & & & \\
\hline Of which: Sub-Sahara & & & \\
\hline Central and Eastern Europe & 2.6 & 4.4 & 3.9 \\
\hline Commonwealth of Independent States and Mongolia & & & \\
\hline Developing Asia, including China & & & \\
\hline Middle East & & & \\
\hline Western Hemisphere & & & \\
\hline Other indicators & & & \\
\hline Gross asset position in financial derivatives to capital & 17.5 & 9.0 & 9.6 \\
\hline Gross liability position in financial derivatives to capital & 17.9 & 10.4 & 11.4 \\
\hline Trading income to total income & 12.4 & 1.5 & 5.5 \\
\hline Personnel expenses to noninterest expenses & 38.3 & 38.5 & 39.1 \\
\hline Spread between reference lending and deposit rates (basis points) & 428.0 & 430.5 & 429.0 \\
\hline Spread between highest and lowest interbank rates (basis points) & & & \\
\hline Customer deposits to total (noninterbank) loans & 98.9 & 117.3 & 115.4 \\
\hline Foreign-currency-denominated loans to total loans & 17.4 & 2.0 & 2.1 \\
\hline Foreign-currency-denominated liabilities to total liabilities & 21.7 & 2.8 & 3.3 \\
\hline Net open position in equities to capital & 9.6 & 10.5 & 10.3 \\
\hline Net open position in foreign exchange to capital & -19.5 & 0.0 & 2.2 \\
\hline
\end{tabular}




\section{Annex I. Medium- and Long-Term Fiscal Issues in Slovakia}

\section{Medium-Term Issues}

\section{Excessive Budget Deficit:}

The size of the general government in Slovakia is relatively small compared to other European countries. As percentage of GDP, both revenue and expenditure are among the lowest in Europe.

\begin{tabular}{l|r|r|r|r|r|r|}
$\begin{array}{l}\text { General Government Fiscal Balance, 2005-10 } \\
\text { (In percent of GDP) }\end{array}$ & $\mathbf{2 0 0 5}$ & $\mathbf{2 0 0 6}$ & $\mathbf{2 0 0 7}$ & $\mathbf{2 0 0 8}$ & $\mathbf{2 0 0 9}$ & $\begin{array}{r}\mathbf{2 0 1 0} \\
\text { (Proj) }\end{array}$ \\
\hline Slovakia & $\mathbf{- 2 . 8}$ & $\mathbf{- 3 . 2}$ & $\mathbf{- 1 . 8}$ & $\mathbf{- 2 . 1}$ & $\mathbf{- 7 . 9}$ & $\mathbf{- 7 . 8}$ \\
\hline Czech Republic & -3.6 & -2.6 & -0.7 & -2.7 & -5.8 & -4.9 \\
\hline Poland & -4.1 & -3.6 & -1.9 & -3.7 & -7.2 & -7.9 \\
\hline Hungary & -7.9 & -9.3 & -5.0 & -3.7 & -4.3 & -4.1 \\
\hline Romania & -0.7 & -1.4 & -3.1 & -4.8 & -7.3 & -6.5 \\
\hline Slovenia & -1.0 & -0.8 & 0.3 & -0.3 & -5.5 & -5.2 \\
\hline Estonia & 1.6 & 3.2 & 2.9 & -2.3 & -2.1 & 0.2 \\
\hline Euro Area & -2.5 & -1.3 & -0.7 & -2.1 & -6.3 & -6.1 \\
\hline Sources: IMF WEO and staff calculations. & & & & \\
& & & & & &
\end{tabular}

\begin{tabular}{|c|c|c|c|c|c|c|}
\hline \multicolumn{7}{|l|}{ (In percent of GDP) } \\
\hline & 2005 & 2006 & 2007 & 2008 & 2009 & $\begin{array}{r}2010 \\
\text { (Proj) }\end{array}$ \\
\hline Slovakia & 35.2 & 33.4 & 32.5 & 32.9 & 33.6 & 33.1 \\
\hline Czech Republic & 41.4 & 41.1 & 41.8 & 40.2 & 40.2 & 40.8 \\
\hline Poland & 39.4 & 40.2 & 40.3 & 39.5 & 37.3 & 38.4 \\
\hline Hungary & 42.2 & 42.7 & 45.1 & 45.1 & 46.1 & 44.6 \\
\hline Romania & 31.4 & 32.3 & 32.3 & 32.2 & 31.4 & 32.8 \\
\hline Slovenia & 41.7 & 41.7 & 40.5 & 41.1 & 40.7 & 41.0 \\
\hline Estonia & 36.8 & 37.8 & 38.2 & 39.2 & 45.5 & 45.7 \\
\hline Euro Area & 44.7 & 45.3 & 45.3 & 44.9 & 44.5 & 44.4 \\
\hline
\end{tabular}

\begin{tabular}{|c|c|c|c|c|c|c|}
\hline \multicolumn{7}{|l|}{ (In percent of GDP) } \\
\hline & 2005 & 2006 & 2007 & 2008 & 2009 & 2010 \\
\hline & & & & & & (Proj) \\
\hline Slovakia & 38.0 & 36.6 & 34.3 & 35.0 & 41.5 & 40.9 \\
\hline Czech Republic & 45.0 & 43.7 & 42.5 & 42.9 & 45.9 & 45.7 \\
\hline Poland & 43.4 & 43.9 & 42.2 & 43.2 & 44.4 & 46.3 \\
\hline Hungary & 50.1 & 52.0 & 50.0 & 48.8 & 50.4 & 48.7 \\
\hline Romania & 32.1 & 33.7 & 35.4 & 37.0 & 38.7 & 39.4 \\
\hline Slovenia & 42.7 & 42.5 & 40.3 & 41.4 & 46.3 & 46.2 \\
\hline Estonia & 35.2 & 34.6 & 35.4 & 41.5 & 47.6 & 45.5 \\
\hline Euro Area & 47.2 & 46.6 & 45.9 & 46.9 & 50.8 & 50.5 \\
\hline
\end{tabular}

Nonetheless, the downturn and the resulting fiscal stimulus have weakened the fiscal position in Slovakia and resulted in one of the highest budget deficits in Europe. Despite the robust GDP growth in 2010, the fiscal deficit remained high due to a permanent revenue loss.
As such, the European Commission has put Slovakia under the Excessive Deficit Procedure (EDP). Slovakia is not a unique example in this context. Other countries have been put under the EDP along with Slovakia. This proposal was based on the fact that the general government deficits exceeded the reference value of 3 percent of GDP in 2009. It sets 2013 as the deadline by which the excessive deficit should be removed. The authorities expressed a strong commitment to fiscal consolidation and decided to accept the timeline set by the European Commission's EDP to bring the deficit below 3 percent of GDP in 2013.

\section{Inefficiency of the VAT Collection System:}

Slovakia has a fairly high share of consumption taxes in total tax revenues relative to other EU countries. Yet, VAT revenue, as percentage of GDP, is the lowest in the region. The standard VAT rate of 20 percent is around the EU average and exemptions or the application of reduced VAT rates are not widespread. 


\begin{tabular}{|c|c|c|c|c|c|c|}
\hline \multicolumn{7}{|c|}{$\begin{array}{l}\text { General Governme } \\
\text { Services, 2005-10 }\end{array}$} \\
\hline \multicolumn{7}{|l|}{ (In percent of GDP) } \\
\hline & 2005 & 2006 & 2007 & 2008 & 2009 & 2010 \\
\hline & & & & & & (Proj) \\
\hline Slovakia & 12.4 & 11.1 & 11.0 & 10.5 & 10.3 & 10.3 \\
\hline Czech Republic & 11.5 & 10.9 & 11.2 & 11.0 & 11.4 & 11.7 \\
\hline Poland & 13.6 & 14.2 & 14.1 & 14.1 & 12.8 & 13.4 \\
\hline Romania & 10.9 & 11.1 & 10.5 & 10.6 & 10.2 & 11.3 \\
\hline Slovenia & 13.6 & 13.1 & 13.0 & 12.9 & 13.2 & 13.3 \\
\hline
\end{tabular}

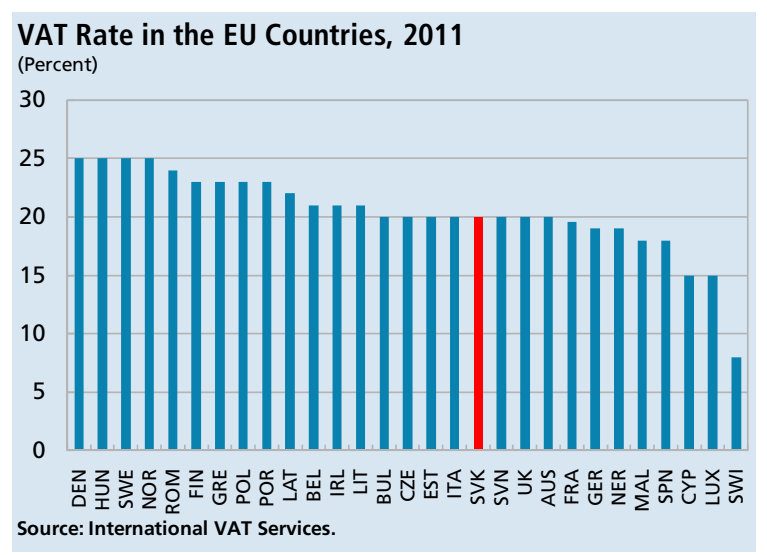

However, the VAT gap is very high in

Slovakia. The VAT gap measures the actual VAT revenues as a ratio of the "theoretical" revenues that could be gained if all goods were taxed at their respective VAT rates. The smaller the gap, the more efficient a country is in collecting VAT. The VAT gap was estimated to stand at 28 percent in 2006, the second highest figure among EU countries and well above the EU average of 12 percent (Reckon, Study to quantify and analyse the VAT in the EU-25 Member States, 2009). This implies that tax collection within the existing regulatory framework is inefficient (OECD, Economic Survey of the Slovak Republic, 2010).

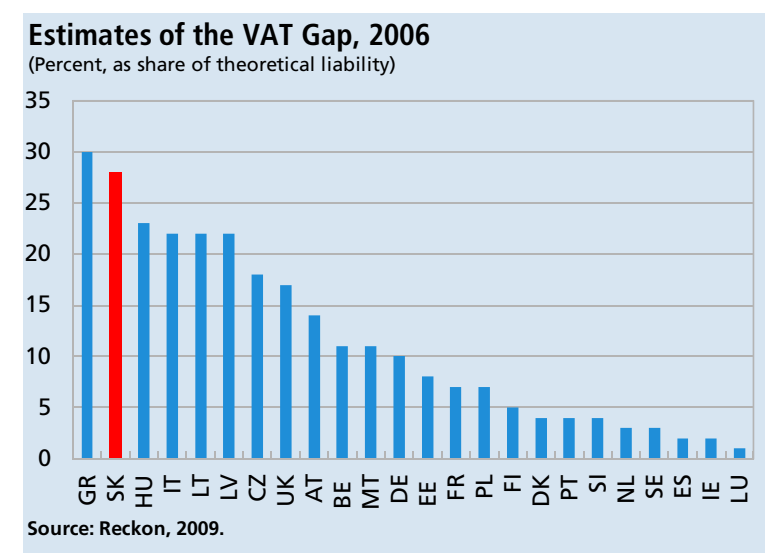

Thus, potential gains can be realized from increasing the effectiveness of VAT collection.

Decreasing the VAT gap to the EU average would increase revenues by more than 1 percent of GDP. For comparison, the 1 percentage point increase in the standard VAT rate introduced in January 2011, while leaving the VAT gap constant, is estimated to yield an increase in revenues of 0.3 percent of GDP (OECD, 2010). Further efficiency gains could be reaped by moving towards unified revenue collection as planned by the government. The gains are estimated to amount to around $2 \frac{1}{2}$ percent of GDP (OECD, 2010).

\section{The High Transition Cost of the Pension System:}

\section{One challenge facing the current Slovak} pension system is the problem of financing considerable transition costs. Out of a total 18 percent of contribution rates, 9 percent is diverted to the Pillar II (privately-managed) system, thus only the remaining 9 percent is retained to cover the expenditure of the Pillar I (pay-as-you-go) system. The magnitude of the contribution diverted to the Pillar $\|$ pension 
funds in Slovakia is larger than that of any other Central or Eastern European country that implemented a similar multi-pillar pension reform. The balance of the pay-as-you-go Pillar I deteriorated due to the misalignment of the number of pensioners and active contributors. While the revenue to the first pillar has decreased due to the diversion of contributions, the current pensioners continue to receive pensions (OECD, 2010).
Contribution Rates for Old-Age Benefits in Selected Central and Eastern European Countries

(In percent)

\begin{tabular}{|l|c|c|c|c|}
\hline & Total & Pillar I & Pillar II & $\begin{array}{c}\text { Share of Pillar II } \\
\text { Contribution Rate }\end{array}$ \\
\hline Slovakia & & & & $\mathbf{9 0} \%$ \\
\hline Romania & 18.0 & $\mathbf{9 . 0}$ & $\mathbf{9 . 0}$ & $9 \%$ \\
\hline Latvia & 29.0 & 26.5 & 2.5 & $10 \%$ \\
\hline Bulgaria & 20.0 & 18.0 & 2.0 & $17 \%$ \\
\hline Hungary & 23.0 & 19.0 & 4.0 & $27 \%$ \\
\hline Croatia & 29.5 & 21.5 & 8.0 & $33 \%$ \\
\hline Macedonia & 15.0 & 10.0 & 5.0 & $35 \%$ \\
\hline Poland & 21.2 & 13.8 & 7.4 & $37 \%$ \\
\hline Source: ILO, 2008. & 19.5 & 12.2 & 7.3 & \\
\hline
\end{tabular}

\section{Box A1 The 2007-08 Amendments to the Pension System}

- For the period from January to June 2008, workers were allowed to move between Pillar I and Pillar || pension systems (the percentage of net number of workers who left Pillar II is about 3 percent).

- Participation in the second pillar has been changed from mandatory to voluntary for new labor market entrants in 2008.

- The qualifying period for pensions was extended from 10 years to 15 years for both Pillar I and Pillar II. Since the Pillar II started in 2005, this implies that workers who were older than 47 years of age in 2005 cannot receive a pension under pillar II.

- The ceiling of the contributory wage has been increased from three times the average wage to four times of that.
- The indexation of pension is made at the average of price inflation and the wage increase (the so-called Swiss indexation), where the weight of each parameter is 0.5 .

- For disabled contributing workers, the State subsidizes their contributions only if they remain in Pillar $\mathrm{I}$.

- Women who have children less than six years of age can voluntarily join Pillar II.

- In 2007, the government approved a Bill to pay Christmas allowance for 1,051,936 pensioners with low level of pensions.

Source: OECD, 2010. 
Long-Term Issues: Age-Related Expenditure

In line with other countries in Central Europe, the old-age dependency ratio in Slovakia is projected to increase by one of the fastest rates among OECD countries. While the ratio of the population aged 65 or above to the labor force is currently much lower in Slovakia than in the OECD, this will change over the next five decades. By 2060, the old age dependency ratio will increase by more than four times to 68.5 percent. One main reason for the fast ageing is the sharp and rapid decline in the fertility rates in the 1990s (European Commission, 2009 Ageing Report, 2009).

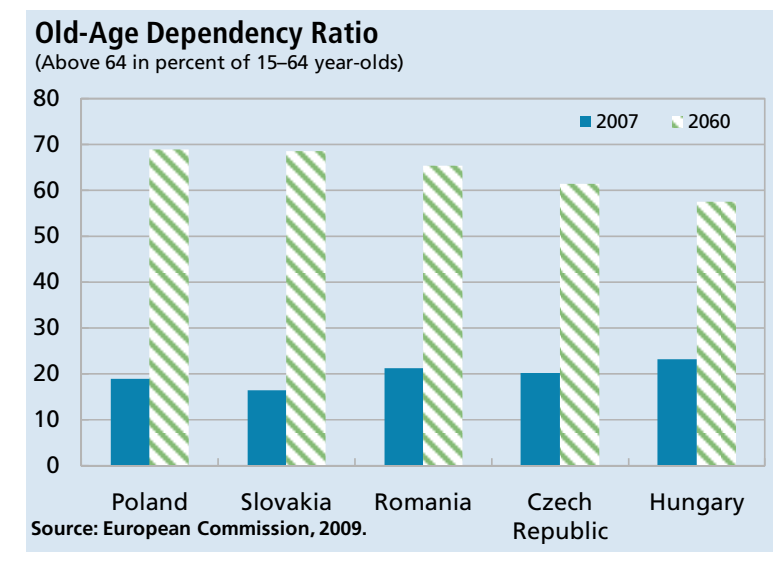

The effects of ageing will put additional pressure on public finances. Total age-related public spending is projected to increase faster in Slovakia than in the rest of the EU based on current policies. Spending will grow by 5.5 percentage points of GDP over the next 50 years compared with average increases of 5.1 and 4.6 percentage points in the euro area and European Union, respectively. The long-term cost of ageing is mainly driven by an increase in pension expenditure (by 3.6 percentage points in 2060 relative to 2010), while health care also contributes to the long-term cost of ageing (increasing by 2.1 percentage points).

\section{Projected Change in Age-Related Spending, 2010-60}

(Percent of GDP)

\begin{tabular}{|l|c|c|c|c|c|c|c|c|c|}
\hline & \multicolumn{3}{|c}{ Pension } & \multicolumn{3}{c|}{ Health Care } & \multicolumn{3}{c|}{ Total } \\
\hline Slovakia & $\mathbf{2 0 1 0}$ & $\mathbf{2 0 6 0}$ & Change & $\mathbf{2 0 1 0}$ & $\mathbf{2 0 6 0}$ & Change & $\mathbf{2 0 1 0}$ & $\mathbf{2 0 6 0}$ & Change \\
\hline Czech Republic & 7.1 & 10.2 & 3.6 & 5.2 & 7.3 & 2.1 & 14.9 & 20.4 & 5.5 \\
\hline Hungary & 11.3 & 11.1 & 4.0 & 6.4 & 8.4 & 2.0 & 17.0 & 23.3 & 6.3 \\
\hline Poland & 10.8 & 8.7 & -2.1 & 4.1 & 4.9 & 0.8 & 19.1 & 18.0 & -1.1 \\
\hline Romania & 8.4 & 15.8 & 7.4 & 3.6 & 4.9 & 1.3 & 14.7 & 23.2 & 8.5 \\
\hline Euro Area & 11.2 & 13.9 & 2.7 & 6.8 & 8.1 & 1.3 & 24.5 & 29.6 & 5.1 \\
\hline EU-27 & 10.2 & 12.5 & 2.3 & 6.8 & 8.2 & 1.4 & 23.2 & 27.8 & 4.6 \\
\hline Source: European Commission, 2009 & & & & & & & \\
\hline
\end{tabular}




\section{Annex II. Slovakia's Financial Sector}

\section{Banking Sector}

The banking sector is relatively concentrated and almost entirely foreign-owned. Almost 70 percent of all banks' assets are managed by four banks: Slovenska Sporitelna, VUB Banka, Tatra Banka, and CSOB Slovakia. These are all foreignowned banks controlled respectively by the Erste Group Bank, Intesa San Paolo, Raiffeisen Zentralbank, and KBC Bank. In addition, foreigners control almost all remaining banks either through subsidiaries or branches. Lending concentration is particularly high for housing loans, where the four largest banks have an 85 percent market share.

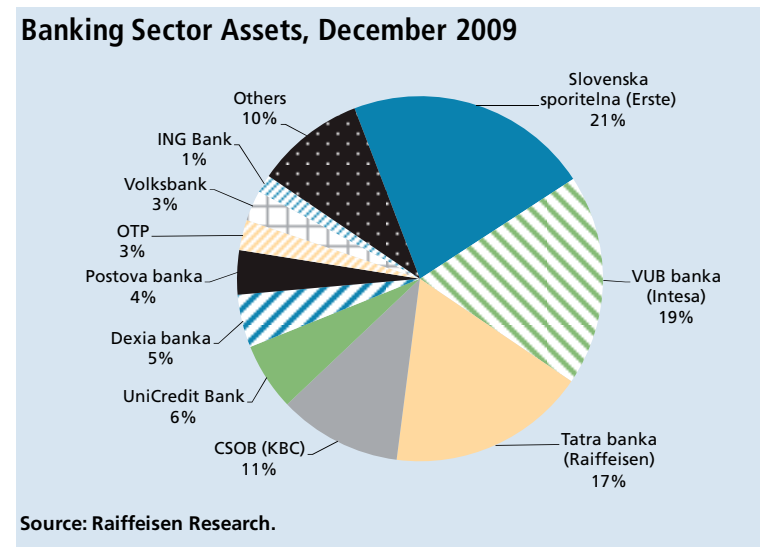

Individual Banks' Share of Housing Loans, February 2011

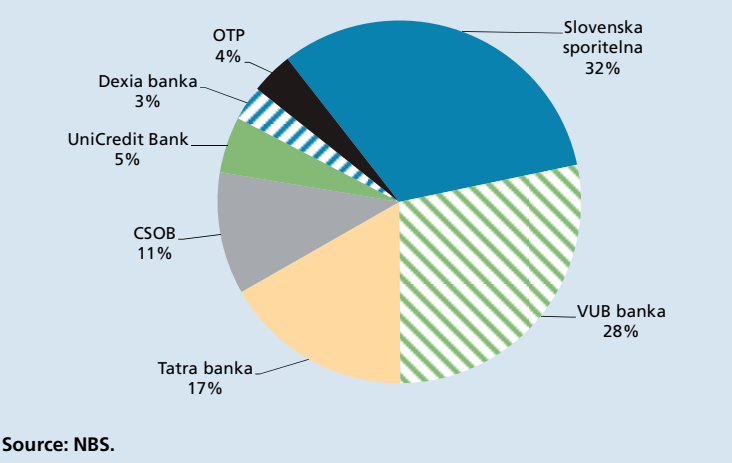

Banks' assets consist mostly of domestic loans and Slovak government securities. Loans account for about 60 percent of banks' assets, fairly evenly distributed between retail and corporate loans with some shift toward retail credit during the crisis. Banks' investment in domestic government bond is large and increased during the crisis. Direct exposure to foreign securities remains limited. Banks held large deposits with the National Bank of Slovakia (NBS) in expectation of appreciation of the Slovak Koruna prior to the Euro adoption on January 1, 2009.
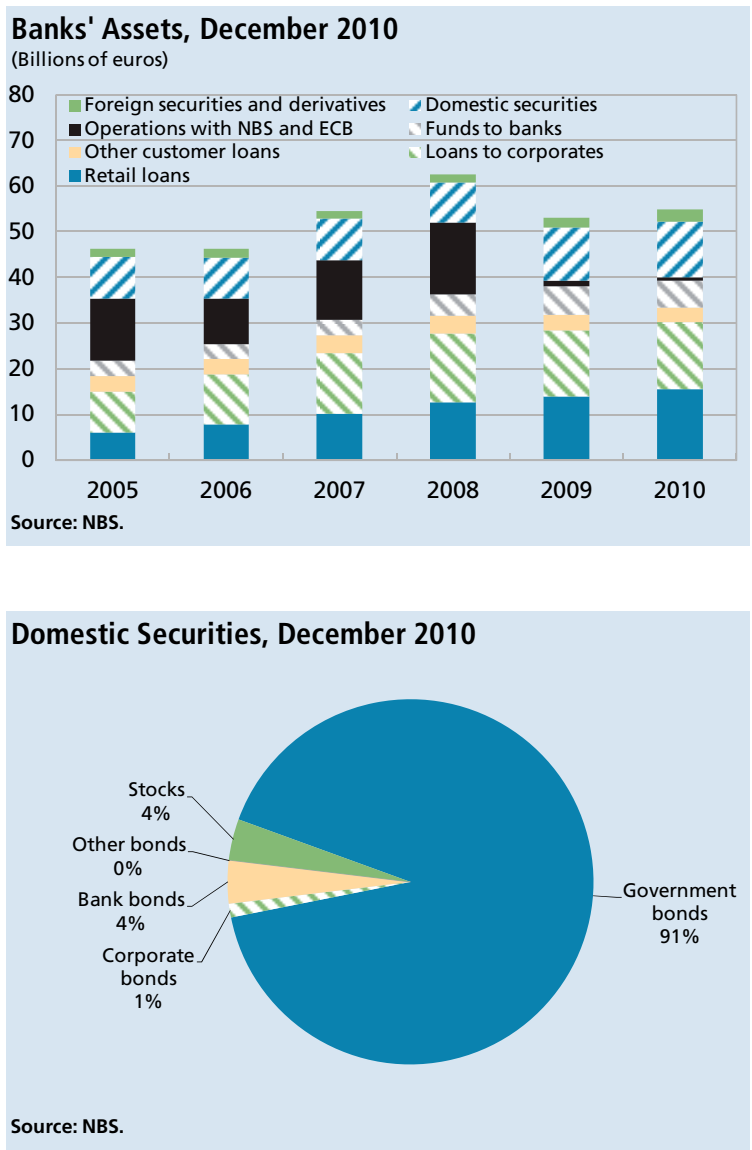


\section{Banks' funding is primarily based on deposits.}

The stability of deposits—coupled with little reliance on wholesale funding - has considerably helped the banking system withstand the financial crisis. To solidify confidence during the crisis, deposits have been entirely insured by the government since October 2008, but up to a limit of euro 100,000 since the beginning of 2011. In addition, banks issue mortgage bonds which are required by domestic regulators to cover at least 70 percent of outstanding mortgage loans. In 2009 banks borrowed euro 2 billions from the ECB and at the same time increased their holdings of government bonds.
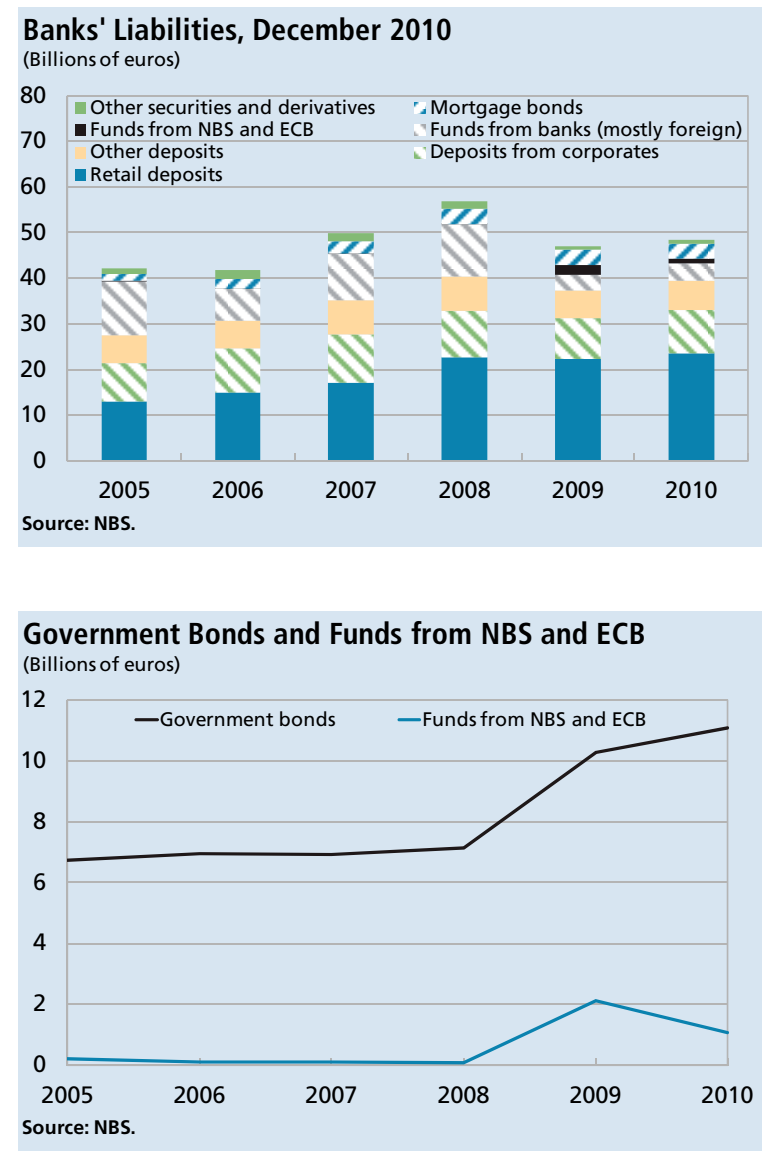

Nonperforming loans have increased significantly during the crisis. The deterioration in the loan portfolio has been somewhat better than in the region as a whole. Nonperforming loans have started to decline in the last quarter of 2010. However, credit risk, especially from loans to the commercial real estate and construction industries, remains a concern.

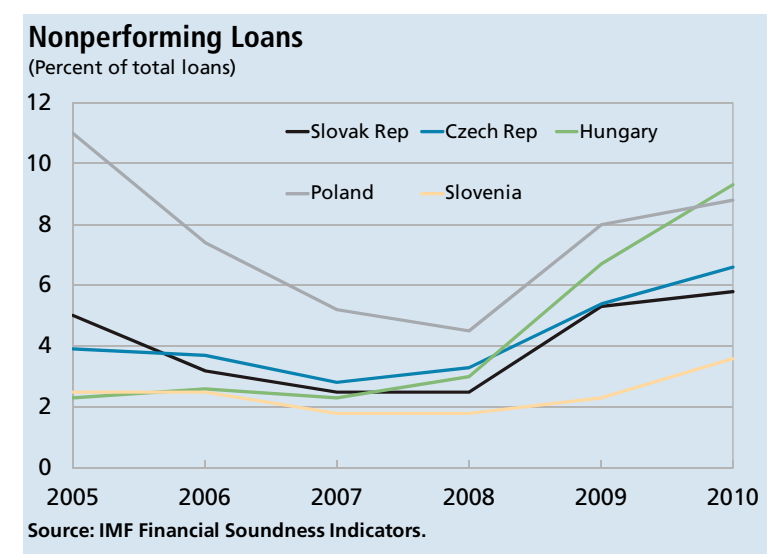

\section{Banks' profits fell considerably during the} crisis, but rebounded in $\mathbf{2 0 1 0}$. The increase in nonperforming loans and the reduction in foreign exchange transactions after the adoption of the euro led to a significant drop in banks' profits. However, profits rebounded in 2010, reflecting cost cutting measures and higher net interest income.

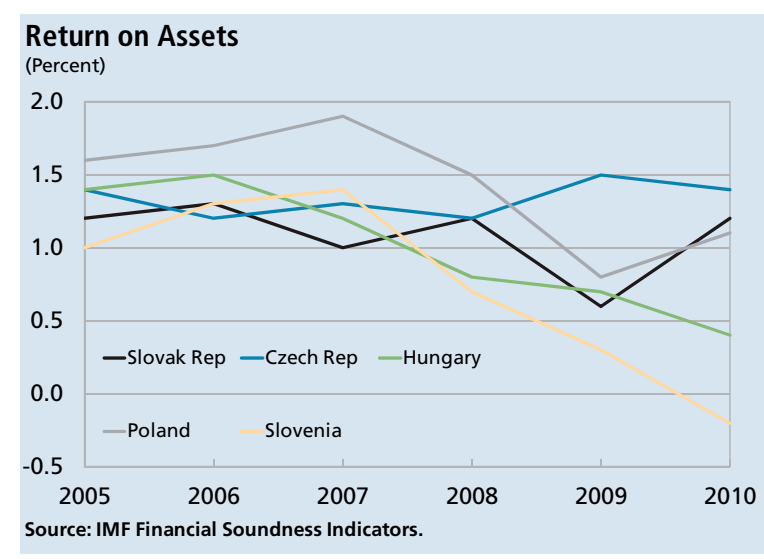




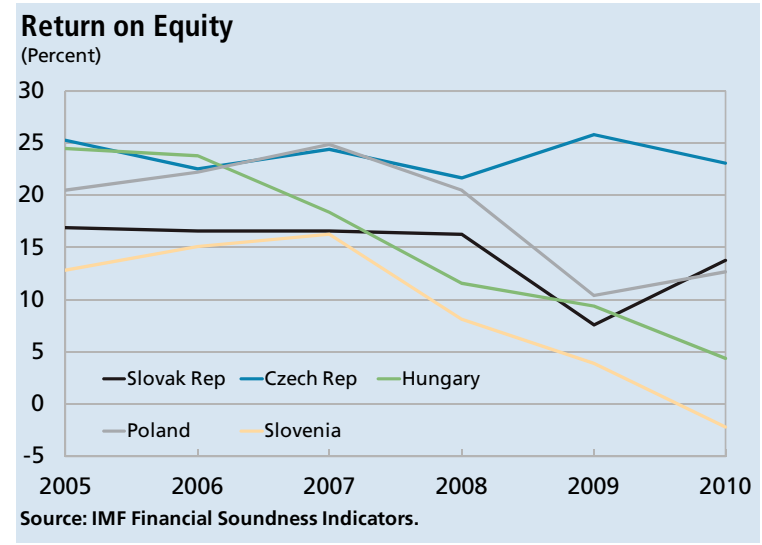

Capital ratios remain at fairly prudent levels. High capital ratios in the early 2000s were progressively reduced by the expansion of loans. The spreading of the international crisis in 2008 has reversed this trend, since banks have reduced riskier loans to enterprises and retained part of the profits to enhance their capital positions.

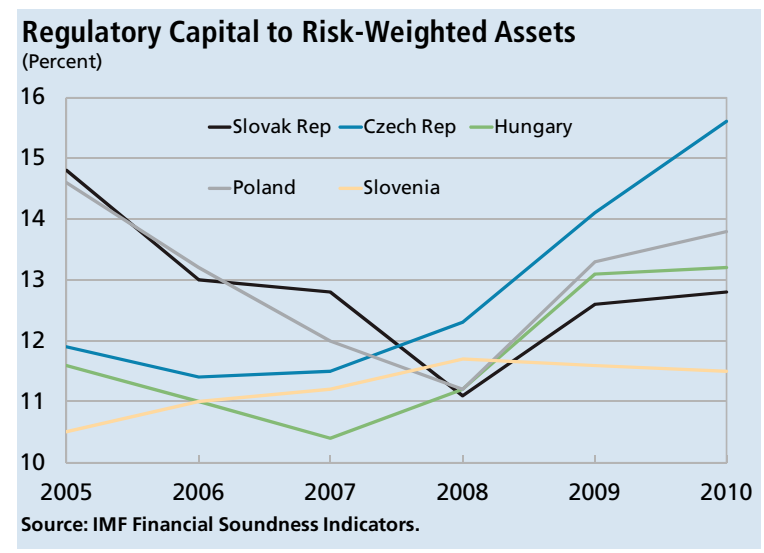

\section{Liquidity is high and the funding base is} stable. The amount of deposits remains sufficient to cover all loans, thus limiting banks' exposure to wholesale markets. To ensure adequate short-term liquidity, the NBS introduced in the second half of 2008 the requirement that liquid assets have to be at least as large as volatile liabilities over a onemonth horizon. This measure of short-tem liquidity slightly improved in 2010 as banks reduced corporate loans and increased investment in government securities. However, while liquidity of euro-area government bonds, including Slovak instruments, is enhanced by ECB repo operations the absence of a well-developed secondary market impairs otherwise the liquidity of domestic government bonds.
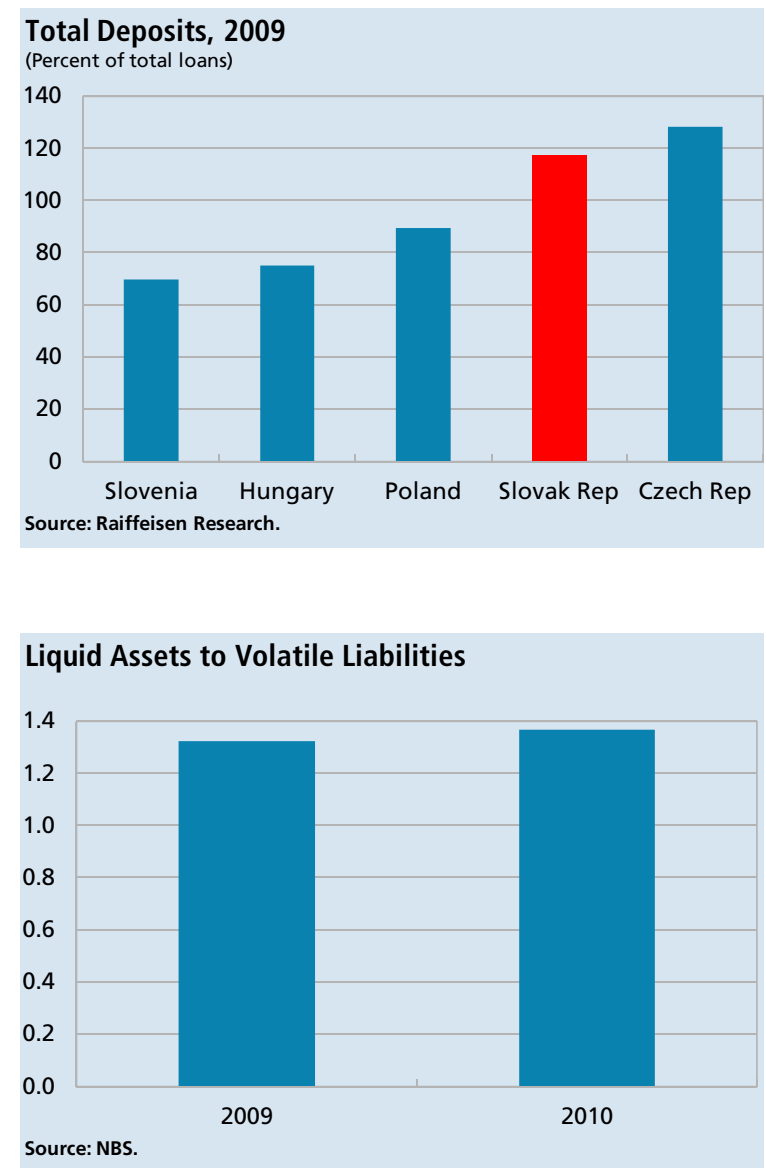

The adoption of Basel III requirements does not seem to pose major challenges. Basel III introduces stricter capital requirements, especially with respect to Tier 1 capital, and the creation of conservation and countercyclical buffers. It also places constraints on the leverage ratio, and requires minimum liquidity standards through the Liquidity Coverage Ratio (LCR), and the Net Stable 
Funding Ratio (NSFR). Slovak banks could meet the new capital requirements relatively easily given their traditional banking model and strong deposit base, especially if the economic recovery sustains profitability. For example, the average capital ratio is already around the 13 percent that would be required in 2019 (including a 2.5 percent countercyclical buffer). Meeting the requirement for Tier 1 capital should also not pose particular problems, since it already constitutes a particularly high share of total capital. Furthermore, the relevance of preferred shares and hybrid instruments is quite limited, as own funds accounts for the majority of Tier 1 capital. Banks are also well placed to achieve the LCR target, while satisfying the NSFR criteria could require more significant adjustments.

\section{Financial Development}

Security markets remain underdeveloped. The stock market capitalization is considerably lower than in comparator countries. This is the case also for the public bond market, and there are no private bond issuances. While large firms affiliated with foreign companies can rely on foreign financing (especially after the adoption of the euro), fostering development in domestic security markets could further improve financing conditions for smaller firms with good growth potential.
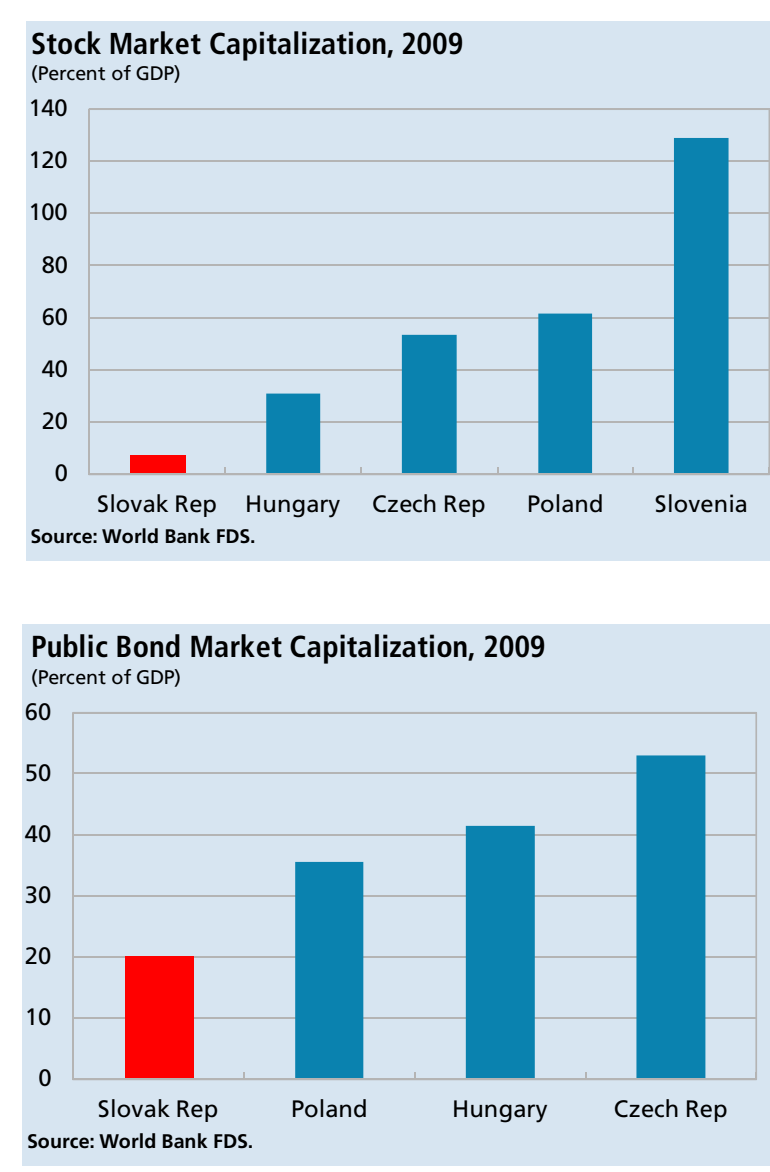

Restrictive rules on pension funds limit investment opportunities. In particular, funds are obliged to provide positive returns every six months and management fees are capped at 0.3 percent of assets. As a consequence, Pillar II investment funds hold low-return safe assets (32 percent of bank deposits and the rest in short-term government bonds), with negligible differentiation among the offered funds. These tight regulations restrict investment options and limit the development of domestic security markets. Households' preference for somewhat more aggressive investment strategies is reflected in the composition of Pillar III funds, which are not subject to the same regulatory requirements and include a considerable share (15 percent) in equities. 


\title{
INTERNATIONAL MONETARY FUND
}

\section{SLOVAK REPUBLIC}

STAFF REPORT FOR THE 2011 ARTICLE IV

May 13, 2011

\section{CONSULTATION-INFORMATIONAL ANNEX}

\author{
Prepared By \\ European Department
}

\section{CONTENTS}

FUND RELATIONS 2 


\section{FUND RELATIONS}

\begin{tabular}{|c|c|c|c|c|c|c|}
\hline \multicolumn{7}{|c|}{ Slovak Republic: Financial Position in the Fund as of March 31, 2011} \\
\hline I. & Membership Status: & \multicolumn{2}{|c|}{ Joined: 01/01/1993; Article VIII } & & & \\
\hline \multirow[t]{5}{*}{ II. } & General Resources Account: & SDR Million & Percent of Quota & & & \\
\hline & Quota & 427.5 & 100 & & & \\
\hline & Fund Holdings of Currency & 308.5 & 72.16 & & & \\
\hline & Reserve Position & 119.01 & 27.84 & & & \\
\hline & Lending to the Fund & 38.33 & & & & \\
\hline \multirow[t]{3}{*}{ III. } & SDR Department: & SDR Million & \multicolumn{2}{|c|}{ Percent of Allocation } & & \\
\hline & Net cumulative allocation & 340.48 & 100 & & & \\
\hline & Holdings & 324.37 & 95.27 & & & \\
\hline IV. & Outstanding Purchases and Loans: & None & & & & \\
\hline \multirow[t]{3}{*}{ V. } & Financial Arrangements: & & & & & \\
\hline & Type & $\begin{array}{c}\text { Date of } \\
\text { Arrangement }\end{array}$ & Expiration Date & $\begin{array}{c}\text { Amount Approved } \\
\text { (SDR Million) }\end{array}$ & $\begin{array}{c}\text { Amount Drawn } \\
\text { (SDR Million) }\end{array}$ & \\
\hline & Stand-by & 7/22/1994 & 3/21/1996 & 115.8 & 32.15 & \\
\hline \multirow{7}{*}{ VI. } & Projected Payments to Fund & & & & & \\
\hline & (SDR Million; based on existing use of re & urces and present hol & ngs of SDRs): & & & \\
\hline & & \multicolumn{4}{|c|}{ Forthcoming } & \\
\hline & & 2011 & 2012 & 2013 & 2014 & 2015 \\
\hline & Principal & & & & & \\
\hline & Charges/Interest & 0.05 & 0.08 & 0.08 & 0.08 & 0.08 \\
\hline & Total & 0.05 & 0.08 & 0.08 & 0.08 & 0.08 \\
\hline
\end{tabular}

\section{Exchange Rate Arrangement:}

The currency of the Slovak Republic is the euro, which was adopted on January 1, 2009.

The Slovak Republic has accepted the obligations of Article VIII and maintains an exchange system that is free of restrictions on the making of payments and transfers for current international transactions. The Slovak Republic maintains exchange restrictions for security reasons, based on UN Security Council Resolutions and Council of the European Union Regulations, that have been notified to the Fund for approval under the procedures set forth in Executive Board Decision No. 144-(52/51).

\section{Article IV Consultation:}

The consultation discussions were held in Bratislava during March 30 through April 12, 2011. The mission met with Minister of Finance Mikloš, National Bank of Slovakia (NBS) Governor Makúch, Minister of Labor, Social Affairs and Family Mihál, other senior government and NBS officials, and representatives of financial institutions, think tanks, trade unions and employers' associations.

The mission comprised Messrs. De Broeck (FIN, head), Mehrez, Abdel-Kader, and Sandri (all 
EUR). The mission's concluding statement was published on the IMF website on April 12, 2011. [The authorities have agreed to the publication of the staff report.]

The previous consultation with the Slovak Republic was concluded on September 3, 2010 (IMF Country Report No. 09/221).

\section{FSAP Participation and ROSCs:}

An FSAP was concluded with the completion of the 2002 Article IV consultation on August 7, 2002 on the basis of missions that took place in February 2002 and April 2002. The FSSA report was published (IMF Country Report No. 02/198). An FSAP update mission was held in December 2006. The FSSA update report was circulated to the Executive Board together with the staff report for the 2007 Article IV Consultation and published on the IMF website on July $17,2007$.

The report on the Fiscal ROSC was issued in August 2002 (IMF Country Report No. 02/189), and updates were issued in August 2003 (IMF Country Report No. 03/236) and in March 2005 (IMF Country Report No. 05/73). The report on the Data ROSC was issued in May 2005 (IMF Country Report No. 05/161).

X. Technical Assistance: See the attached table.

XI. Resident Representative Post: None (closed at end-April 2004). 


\section{Slovakia: Technical Assistance, 2000-11 1/}

\section{Department}

Timing

Purpose

\begin{tabular}{|c|c|c|}
\hline \multirow[t]{3}{*}{ MFD } & February 2000 & $\begin{array}{l}\text { Mission on pros and cons, and modalities of moving to } \\
\text { an inflation targeting framework, operational issues } \\
\text { (money markets and policy instruments), and dealing } \\
\text { with potential problems posed by capital inflows for } \\
\text { monetary operations }\end{array}$ \\
\hline & December 2001 & Long-term resident expert on banking supervision \\
\hline & May 2002 & Two missions on inflation modeling \\
\hline \multirow[t]{10}{*}{ FAD } & April 2000 & Tax administration \\
\hline & February 2001 & Tax administration (follow-up) \\
\hline & April 2001 & Public Finance Management (follow-up) \\
\hline & August 2001 & $\begin{array}{l}\text { Tax administration: installation of resident expert to } \\
\text { advise on establishment of Large Taxpayer Unit (LTU) }\end{array}$ \\
\hline & $\begin{array}{l}\text { August 2001-August } \\
2002\end{array}$ & $\begin{array}{l}\text { Regular visits by FAD consultant on establishment of } \\
\text { LTU }\end{array}$ \\
\hline & December 2001 & $\begin{array}{l}\text { Tax administration follow-up, tax investigation/fraud } \\
\text { issues }\end{array}$ \\
\hline & June 2002 & $\begin{array}{l}\text { Mission to prepare Report on the Observance of } \\
\text { Standards and Codes (ROSC), Fiscal Transparency } \\
\text { Module }\end{array}$ \\
\hline & February 2003 & Tax policy \\
\hline & March 2003 & Tax administration \\
\hline & May 2003 & Expenditure policy \\
\hline \multirow[t]{4}{*}{ STA } & February 2000 & National accounts and price statistics \\
\hline & March 2001 & Multisector mission \\
\hline & July 2003 & Government finance statistics \\
\hline & February-March 2004 & Data ROSC Mission \\
\hline
\end{tabular}




\section{STATISTICAL ISSUES}

Coverage, periodicity, and timeliness of data provided to the Fund are adequate for surveillance purposes. From the point of view of macroeconomic analysis and policy making, significant data improvements have been made in recent years, particularly in the national accounts. A data ROSC mission during February-March 2004 found that the integrity, methodological soundness, and reliability of the data were satisfactory, despite some shortcomings in the data revision policy. The main issues remaining are: (i) weaknesses in the data on prices and volumes of imports and exports; (ii) a lack of timely data on the general government operations; and (iii) slow compilation cycle of the annual national accounts and lack of proper benchmarking of quarterly data. The Slovak Republic subscribes to the Special Data Dissemination Standard (SDDS) since 1996 and observes or exceeds all related standards.

With regard to timeliness and public access, the authorities in general follow a free and open data publication policy. Data are promptly released to news services, and are also published regularly in various monthly and quarterly statistical publications, and on the
Internet ${ }^{1}$ according to a pre-announced schedule. Data on core surveillance variables are provided regularly to the Fund, and with minimal lags: a week or less for foreign exchange reserves; a day for monthly state budget implementation data; 10 days to a month for consumer prices, reserve money, broad money, and interest rates; two months for foreign trade data; and about three months for other fiscal, balance of payments, and national accounts data.

\section{Real Sector and Prices}

Significant progress has been made in the compilation of the national accounts statistics. However, the quarterly national accounts data on expenditures exhibit weaknesses and there is a significant statistical discrepancy between the supply side and the demand side. An important outstanding issue is the compilation of reliable price deflators for imports and exports that would enable better decomposition into volume and price changes. The unit value trade price indices-on which the national accounts trade

\footnotetext{
${ }^{1}$ Data are available on the website of the Slovak Statistics Office (www.statistics.sk), the National Bank of Slovakia (NBS) (www.nbs.sk), and the ministry of finance (MoF) (www.finance.gov.sk).
} 
price deflators are based-are published with long delays and are not appropriately adjusted for quality changes. The statistical authorities are aware of these issues and improvements are pending.

Following the fast development of chain stores, which are not fully captured in surveys, the authorities consider that retail sales and the level of consumption might be biased (especially if compared to VAT receipts), and wage statistics also might be biased.

In the enterprise sector, it would be very useful if the line ministries produced systematic accounts of the financial positions of the public enterprises under their purview.

\section{Fiscal Sector}

General government statistics are compiled annually in accordance with the methodology of the ESA95, and disseminated on the Ministry of Finance (MOF) website. In accordance with the EU acquis communautaire, the authorities report semi-annually on general government net lending/borrowing on ESA95 basis. Monthly reconciliation of government operations above and below-the-line is restricted to state budget transactions on a cash basis. A modern treasury system has been operating since January 2004. The new system has improved fiscal control and public debt management by allowing the recording of expenditures at the planning and commitment stages.

The MOF has converted its fiscal accounts to ESA95 standards. The MOF compiles Government Finance Statistics according to the Government Finance Statistics Manual 2001 (GFSM 2001) analytical framework; data are available and disseminated on a cash basis for 1996-2005, and on an accrual basis for 2003-09.

\section{External Sector}

External sector statistics are of good quality, and are reported on a timely basis to the Fund.

\section{Monetary Sector}

Monetary statistics are of good quality, and are reported on a timely basis to the Fund. 


\section{Slovakia: Table of Common Indicators Required for Surveillance (as of April 29, 2011)}

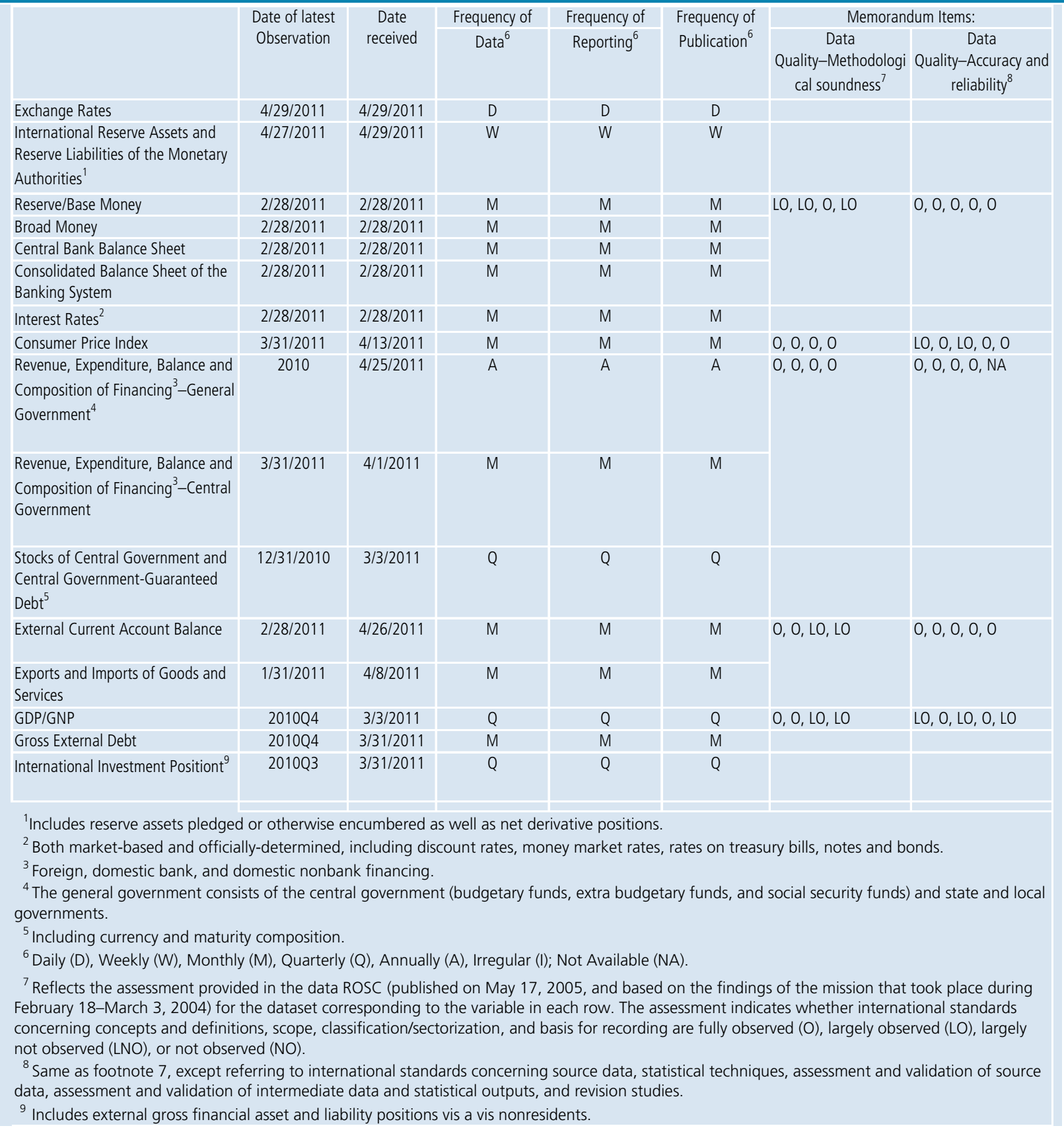




\section{INTERNATIONAL MONETARY FUND}

EXTERNAL

Public Information Notice (PIN) No. 11/68

FOR IMMEDIATE RELEASE

May 31, 2011
International Monetary Fund

$70019^{\text {th }}$ Street, NW

Washington, D. C. 20431 USA

\section{IMF Executive Board Concludes 2011 Article IV Consultation with Slovak Republic}

On May 25, 2011 the Executive Board of the IMF concluded the Article IV consultation with the Slovak Republic, and considered and endorsed the staff appraisal without a meeting. ${ }^{1}$

\section{Background}

The Slovak economy has continued its robust recovery. The upturn has been stronger than in most of Slovakia's neighbors reflecting strong fundamentals and a surge in the export-oriented manufacturing sector, which benefited from a revival in global demand. In tandem, the financial sector has regained strength, profits in the corporate sector are recovering, real estate prices have stabilized, and the fiscal position is improving.

The growth outlook for 2011 and beyond is favorable. While growth will still be driven mainly by the export sector, a gradual rebound in domestic demand would provide some boost and broadly offset the withdrawal of fiscal support. Overall, staff projects real GDP growth of about $33 / 4$ percent in 2011 and of about $4 \frac{1}{4}$ percent in 2012-15, among the strongest performances in the European Union, but still significantly below the pre-crisis rate of expansion.

The economic recovery has had little positive effect on employment. The unemployment rate, has climbed to over 14 percent, and is even higher among low-skilled workers and in less

\footnotetext{
${ }^{1}$ Under Article IV of the IMF's Articles of Agreement, the IMF holds bilateral discussions with members, usually every year. A staff team visits the country, collects economic and financial information, and discusses with officials the country's economic developments and policies. On return to headquarters, the staff prepares a report, which forms the basis for discussion by the Executive Board. At the conclusion of the discussion, the Managing Director, as Chairman of the Board, summarizes the views of Executive Directors, and this summary is transmitted to the country's authorities. An explanation of any qualifiers used in summing ups can be found here: http://www.imf.org/external/np/sec/misc/qualifiers.htm.
} 
prosperous regions. With the turnaround in economic activity, employment started to recover in late 2010, but the gains, so far, have been small and insufficient to prevent an increase in longterm unemployment.

Inflation dropped to among the lowest in the euro zone in 2010, but accelerated in early 2011. Reflecting the global increase in the price of oil and other commodities, and in part because of indirect tax hikes at the beginning of 2011, CPI inflation jumped to 3.8 percent (year-on-year) in March. However, as core inflation remains well-anchored, the projected tightening of monetary conditions will help reduce CPI inflation to below 3 percent in 2012 and beyond.

The 2011 budget includes a significant fiscal consolidation package that is projected to reduce the general government deficit to about 5 percent of GDP. A structural drop in revenue and continued strong expenditure growth kept the fiscal deficit in 2010 at around 8 percent of GDP for a second year in a row. The high deficits contributed to a rapid increase in the general government debt to around 41 percent of GDP. Yet, this ratio is still relatively low, and market confidence has remained intact—reflected in a relatively low risk premium over corresponding euro zone benchmark bonds.

Financial conditions and the situation of the financial sector have improved. Credit growth is recovering gradually, and monetary conditions are supportive with a low interest rate. Banks have enhanced their balance sheet and improved capital and liquidity ratios. Their profits rebounded in 2010, reflecting cost cutting measures, higher interest rate spreads and lower provisions, notwithstanding a still high level of nonperforming loans.

\section{Executive Board Assessment}

In concluding the 2010 Article IV consultation with the Slovak Republic, Executive Directors endorsed the staff's appraisal, as follows:

The Slovak economy is recovering from the sharp recession. The immediate priorities are to restore fiscal sustainability and address the high unemployment, while over the medium term maintaining external competitiveness within the monetary union should be a key objective.

The sharp deterioration in the fiscal position, which largely reflects structural weaknesses, is a concern. In this regard, the front-loaded fiscal adjustment of about $2 \frac{1}{2}$ percentage points of GDP in 2011, and the authorities' strong commitment to bring the fiscal deficit down to below the Maastricht norm in 2013 are welcomed. The adjustment properly balances the dual objectives of ensuring fiscal sustainability and allowing the recovery to continue.

To spread the burden over time and enhance market confidence, the 2011 adjustment should be anchored within a clear medium-term fiscal consolidation strategy. This could be facilitated by adopting a real expenditure growth ceiling consistent with deficit targets and expenditure policy priorities, including reforming health care and pensions. In addition to containing expenditure, revenue measures, including raising indirect taxes and eliminating exemptions, will also be necessary. 
The resilience of the banking sector in the face of the global crisis is encouraging. The supervisory authority's proactive response to the crisis and the confirmation by stress test results of the ability of the sector to absorb a variety of severe shocks are welcomed. Continued close monitoring of banking sector developments, in particular lending to corporate and real estate sectors, will nevertheless remain essential. In light of the large share of foreign ownership in Slovak banks, enhancing cross-border supervisory coordination is essential.

The increase in long-term unemployment, particularly among low-skilled workers is regrettable. The authorities should remove structural impediments to employment, including by strengthening higher education and vocational programs and enhancing active labor market policies. The authorities' initiative to improve the labor market prospects of low-skilled workers through a combination of reduced social security contributions and in-job benefits are welcome.

External competitiveness has been preserved in recent years with wages growing in line with productivity, and Slovakia's market share in global exports continuing to expand. However, maintaining competitiveness in the monetary union will require sustained structural reforms. In addition to labor market and educational reforms, enhancing the business environment and strengthening public sector governance, with a special emphasis on public procurement and the absorption of EU funds are important.

Public Information Notices (PINs) form part of the IMF's efforts to promote transparency of the IMF's views and analysis of economic developments and policies. With the consent of the country (or countries) concerned, PINs are issued after Executive Board discussions of Article IV consultations with member countries, of its surveillance of developments at the regional level, of post-program monitoring, and of ex post assessments of member countries with longer-term program engagements. PINs are also issued after Executive Board discussions of general policy matters, unless otherwise decided by the Executive Board in a particular case. 
Table 1. Slovak Republic: Summary of Economic Indicators, 2006-12

(As percent of World GDP)

\begin{tabular}{|c|c|c|c|c|c|c|c|}
\hline & \multirow[b]{2}{*}{2006} & \multirow[b]{2}{*}{2007} & \multirow[b]{2}{*}{2008} & \multirow[b]{2}{*}{2009} & \multirow[b]{2}{*}{2010} & \multicolumn{2}{|c|}{ Projections } \\
\hline & & & & & & 2011 & 2012 \\
\hline & \multicolumn{7}{|c|}{$\begin{array}{c}\text { (Annual percentage change, constant prices, unless noted } \\
\text { otherwise) }\end{array}$} \\
\hline Real GDP & 8.5 & 10.5 & 5.8 & -4.8 & 4.0 & 3.8 & 4.2 \\
\hline Domestic demand & 6.6 & 6.4 & 5.7 & -7.9 & 2.7 & 1.8 & 3.6 \\
\hline Public consumption & 9.7 & 0.1 & 6.1 & 5.6 & 0.1 & 0.2 & 1.7 \\
\hline Private consumption & 5.9 & 6.8 & 6.2 & 0.3 & -0.3 & 2.3 & 3.8 \\
\hline Gross capital formation & 6.1 & 9.7 & 4.7 & -31.0 & 12.9 & 1.7 & 4.7 \\
\hline Net exports (contributions to growth) & 2.1 & 4.7 & 0.1 & 2.0 & 2.1 & 1.5 & 0.8 \\
\hline Exports of goods and services & 21.0 & 14.3 & 3.1 & -15.9 & 16.4 & 8.5 & 6.6 \\
\hline Imports of goods and services & 17.8 & 9.2 & 3.1 & -18.6 & 14.9 & 7.5 & 6.3 \\
\hline \multicolumn{8}{|l|}{ Prices } \\
\hline Inflation (CPI) & 4.3 & 1.9 & 3.9 & 0.9 & 0.7 & 3.4 & 2.7 \\
\hline Inflation (CPI, end of period) & 3.5 & 2.4 & 3.5 & 0.1 & 1.3 & 3.4 & 2.9 \\
\hline \multicolumn{8}{|l|}{ Employment and wages } \\
\hline Employment & 3.8 & 2.4 & 3.2 & -2.8 & -2.1 & 1.9 & 1.6 \\
\hline Nominal wages & 6.7 & 6.4 & 7.6 & 2.4 & 5.4 & 4.0 & 6.5 \\
\hline \multirow[t]{2}{*}{ Unemployment rate (percent) } & 13.3 & 11.0 & 9.6 & 12.1 & 14.4 & 13.3 & 12.1 \\
\hline & \multicolumn{7}{|c|}{ (Percent of GDP) } \\
\hline \multicolumn{8}{|l|}{ Public Finance, General Government } \\
\hline Revenue & 33.4 & 32.5 & 32.9 & 33.6 & 33.1 & 33.1 & 32.7 \\
\hline Expenditure & 36.6 & 34.3 & 35.0 & 41.5 & 40.9 & 37.9 & 36.3 \\
\hline Overall balance & -3.2 & -1.8 & -2.1 & -7.9 & -7.8 & -4.9 & -3.7 \\
\hline Primary balance & -1.7 & -0.4 & -0.8 & -6.5 & -6.4 & -3.2 & -1.9 \\
\hline \multirow[t]{2}{*}{ General government debt } & 30.5 & 29.6 & 27.8 & 35.4 & 41.7 & 44.4 & 45.4 \\
\hline & \multicolumn{7}{|c|}{ (Percent) } \\
\hline \multicolumn{8}{|l|}{ Monetary and financial indicators } \\
\hline Bank credit to private sector (growth rate) 1/ & 23.9 & 22.2 & 15.6 & 1.0 & 3.4 & & \\
\hline Lending rates $2 /$ & 9.2 & 9.3 & 8.1 & 6.9 & 6.8 & & \\
\hline Deposit rates $3 /$ & 0.9 & 0.8 & 0.7 & 0.3 & 0.2 & & \\
\hline \multirow[t]{2}{*}{ Government 10 -year bond yield } & 4.4 & 4.5 & 4.7 & 4.7 & 3.9 & & \\
\hline & \multicolumn{7}{|c|}{ (Percent of GDP) } \\
\hline \multicolumn{8}{|l|}{ Balance of payments } \\
\hline Trade balance (goods) & -4.7 & -1.2 & -1.1 & 1.9 & 0.8 & 0.6 & 0.5 \\
\hline Current account balance & -7.8 & -5.3 & -6.6 & -3.6 & -3.4 & -2.8 & -2.7 \\
\hline Gross external debt & 51.0 & 54.5 & 56.3 & 71.9 & 72.1 & 70.4 & 67.8 \\
\hline
\end{tabular}

Sources: National Authorities; and IMF staff calculations.

1/ Last data point 30 September 2010.

2/ Loans of up to one year, non-housing new loans to households.

$3 /$ Average of interest rates on new overnight deposits from households and nonfinancial corporations. 